\title{
$a_{2 A^{-}}$and $a_{2 c^{-}}$-Adrenoceptors as Potential Targets for Dopamine and Dopamine Receptor Ligands
}

\author{
Marta Sánchez-Soto ${ }^{\star}, \neq, 1$, Verònica Casadó-Anguera ${ }^{\ddagger}, 1$, Hideaki Yano*, Brian Joseph \\ Bender $\$$, I, Ning-Sheng Cai ${ }^{\star}$, Estefanía Moreno ${ }^{\ddagger}$, Enric I Canela ${ }^{\ddagger}$, Antoni Cortés ${ }^{\ddagger}$, Jens

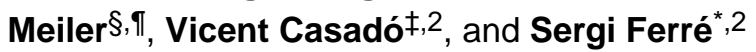 \\ "Integrative Neurobiology Section, National Institute on Drug Abuse, Intramural Research \\ Program, National Institutes of Health, Baltimore, Maryland 21224 \\ FDepartment of Biochemistry and Molecular Biomedicine, Faculty of Biology, University of \\ Barcelona, and Centro de Investigación Biomédica en Red sobre Enfermedades \\ Neurodegenerativas (CIBERNED), and Institute of Biomedicine of the University of Barcelona, \\ 08028 Barcelona, Spain \\ §Department of Pharmacology, Vanderbilt University, Nashville, Tennessee 37232 \\ ^Center for Structural Biology, Vanderbilt University, Nashville, Tennessee 37232
}

\section{Abstract}

The poor norepinephrine innervation and high density of Gi/o-coupled $a_{2 \mathrm{~A}}$ and $\mathrm{a}_{2 \mathrm{C}}$ adrenoceptors in the striatum and the dense striatal dopamine innervation have prompted the possibility that dopamine could be an effective adrenoceptor ligand. Nevertheless, the reported adrenoceptor agonistic properties of dopamine are still inconclusive. In this study, we analyzed the binding of norepinephrine, dopamine and several compounds reported as selective dopamine $\mathrm{D}_{2}$-like receptor ligands, such as the $\mathrm{D}_{3}$ receptor agonist 7-OH-PIPAT and the $\mathrm{D}_{4}$ receptor agonist RO-105824, to $a_{2}$ adrenoceptors in cortical and striatal tissue, which express $a_{2 A}$ adrenoceptors and both $a_{2 A}$ and $a_{2 C}$ adrenoceptors, respectively. The affinity of dopamine for $a_{2}$ adrenoceptors was found to be similar to that for $\mathrm{D}_{1}$-like and $\mathrm{D}_{2}$-like receptors. Moreover, the exogenous dopamine receptor ligands also showed high affinity for $\mathrm{a}_{2 \mathrm{~A}}$ and $\mathrm{a}_{2 \mathrm{C}}$ adrenoceptors. Their ability to activate Gi/o proteins through $a_{2 \mathrm{~A}}$ and $\mathrm{a}_{2 \mathrm{C}}$ adrenoceptors was also analyzed in transfected cells with bioluminescent resonance energy transfer techniques. The relative ligand potencies and efficacies were dependent on the Gi/o protein subtype. Furthermore, dopamine binding to $a_{2}$ adrenoceptors was functional, inducing changes in dynamic mass redistribution, adenylyl cyclase activity and ERK1/2 phosphorylation. Binding events were further studied with computer modeling of ligand docking. Docking of dopamine at $a_{2 \mathrm{~A}}$ and $\mathrm{a}_{2 \mathrm{C}}$ adrenoceptors was nearly identical to its binding to

\footnotetext{
${ }^{2}$ To whom correspondence should be addressed: Sergi Ferré, Integrative Neurobiology Section, National Institute on Drug Abuse, Intramural Research Program, Triad Technology Building, 333 Cassell Drive, Baltimore, Maryland 21224. sferre@ Intra.nida.nih.gov. Vicent Casadó, Department of Biochemistry and Molecular Biomedicine, Faculty of Biology, University of Barcelona, Diagonal 643, 08028 Barcelona, Spain.vcasado@ub.edu.

${ }_{1}^{1}$ Both authors contributed equally to this work

Conflict of interests: The authors declare no conflicts of interest

Author contributions: M. S.-S., V. C.-A., H. Y., N.-S. C, E. M., A. C., and B. J. B. performed the experiments and analyzed the data. H. Y., B. J. B., J. M., V. C. and S. F., designed the experiments. M. S.-S., V. C.-A., H. Y., B. J. B., J. M., E. I. C., V. C. and S. F., wrote the manuscript.
} 
the crystallized $D_{3}$ receptor. Therefore, we provide conclusive evidence that $a_{2 A}$ and $a_{2 C}$ adrenoceptors are functional receptors for norepinephrine, dopamine and other previously assumed selective $\mathrm{D}_{2}$-like receptor ligands, which calls for revisiting previous studies with those ligands.

\section{Keywords}

$\mathrm{a}_{2}$-adrenoceptors; BRET; DMR; adenylyl cyclase; ERK1/2 phosphorylation; docking

\section{Introduction}

The neurotransmitter norepinephrine (NE) binds and activates three subfamilies of adrenoceptors: $\alpha_{1}$-adrenoceptors, subdivided into $a_{1 A}, a_{1 B}$ and $\alpha_{1 D} ; a_{2}$-adrenoceptors, subdivided into $\alpha_{2 A}, a_{2 B}$ and $a_{2 C}$; and $\beta$-adrenoceptors, subdivided into $\beta_{1}, \beta_{2}$ and $\beta_{3}$ [1]. Classically, $\alpha_{1^{-}}, \alpha_{2^{-}}$and $\beta$-adrenoceptors couple to $\mathrm{Gq} / 11$, Gi/o and Gs, respectively [1,2]. In mammalian species, $\alpha_{2 A}$ is the main subtype in most brain regions whereas $a_{2 B}$ subtype has a limited distribution and is mostly expressed in the thalamus [3,4]. The $a_{2 C}$ subtype is found with particularly high density in the striatum $[5,6]$ with a moderately lower density than $a_{2 A}[7,8]$. The high density of dorsal striatal $a_{2 A}$ and $a_{2 C}$ adrenoceptors prompted a fundamental question in view of the well-known paucity of striatal noradrenergic terminals [9-11] and the concomitant low extracellular levels of striatal NE [12]. Yet, a series of studies indicate that both types of receptors are fully functional in the striatum, where they seem to be localized mostly postsynaptically, preferentially in GABAergic striatal efferent neurons $[13,14]$. There is also evidence for $a_{2 A}$ adrenoceptors playing a role as autoreceptors localized in the sparse striatal noradrenergic terminals [15]. It was postulated by Zhang et al., [16] that dopamine (DA) could provide the endogenous neurotransmitter for striatal $a_{2}$ adrenoceptors. In transfected mammalian cells, using radioligand binding experiments, they found only a small preferential affinity of NE versus DA at both $a_{2 A}$ and $a_{2 C}$ adrenoceptors. Similar results were more recently obtained from radioligand binding studies using transfected mammalian and insect cell lines [17] and with radioligand binding and autoradiographic experiments in bird and rat brain with a non-selective $a_{2}$ adrenoceptor ligand [18]. However, Zhang et al., [16] reported a much lower potency of DA (in the micromolar range) than NE (in the nanomolar range) at the level of $a_{2 C}$ adrenoceptormediated signaling (modulation of forskolin-induced adenylyl cyclase activation).

Due to the mismatch between dopaminergic and noradrenergic innervation and the density of their receptors in several brain areas, the controversy about the differential binding affinity of DA versus NE on adrenoceptors and the potential functional efficacy of this binding, we wanted to study in detail the ability of DA and several synthetic DA receptor ligands to bind to the orthosteric site of $a_{2}$ adrenoceptors in transfected cells and in sheep brain. Moreover, we further analyzed the ability of these ligands to generate functional responses: activation of G proteins, inhibition of cAMP accumulation, and ERK1/2 phosphorylation. In the present study, we first analyzed the ability of DA and several DA receptor ligands to bind to $a_{2}$ adrenoceptors in cortical tissue, which predominantly expresses $a_{2 \mathrm{~A}}$ adrenoceptors, and striatal tissue, which expresses both $\mathrm{a}_{2 \mathrm{~A}}$ and $\mathrm{a}_{2 \mathrm{C}}$ 
adrenoceptors. We also studied the potential dopaminergic function of $a_{2 \mathrm{~A}}$ and $\mathrm{a}_{2 \mathrm{C}}$ adrenoceptors using the same methodology that recently allowed us to demonstrate the potent activation of all Gi/o-coupled DA $\mathrm{D}_{2}$-like receptors by NE [19]. This methodology consists on sensitive Bioluminescent Resonance Energy Transfer (BRET)-based techniques that allow detection of ligand-dependent interactions between specific receptors and specific $\mathrm{G}$ proteins ( $\mathrm{G}$ protein activation) or receptor-induced activation of effectors (adenylyl cyclase activity) in living cells [19]. Moreover, we compared the ability of NE, DA and DA receptor ligands to modulate dynamic mass redistribution (DMR) and to activate MAPK signaling. Lastly, we modeled the binding of DA at $\mathrm{a}_{2 \mathrm{~A}}$ and $\mathrm{a}_{2 \mathrm{C}}$ adrenoceptors, as compared to its binding to the crystallized $\mathrm{D}_{3}$ receptor. Our results provide conclusive evidence for $a_{2 A}$ and $a_{2 C}$ adrenoceptors being not only NE but also DA receptors and common targets for other $\mathrm{D}_{2}$-like receptor ligands.

\section{Materials and Methods \\ DNA Constructs and Transfection}

For BRET experiments, human receptor constructs were used for $a_{2 A}$ and $a_{2 C}$ adrenoceptors (cDNA Resource Center). The following human G protein constructs were used: Gai1-, Gai2-, Gai3-, Gao1-, or Gao2-Renilla luciferase 8 (RLuc8) with RLuc8 inserted at position 91, untagged $\mathrm{G} \beta 1$, and $\mathrm{G} \gamma 2$ fused to full-length mVenus at its $\mathrm{N}$ terminus. The Ga-RLuc8 constructs were kindly provided by Céline Galés (INSERM, Toulouse, France). The cAMP sensor using YFP-Epac-Rluc (CAMYEL) biosensor was obtained from the American Type Culture Collection (no. MBA-277; ATCC, Manassas, VA) [20]. All the constructs were confirmed by sequencing analysis. A constant amount of plasmid cDNA ( $0.5 \mu \mathrm{g}$ Ga-RLuc8, $4.5 \mu \mathrm{g}$ G $\beta 1,5 \mu \mathrm{g}$ G $\gamma 2$-mVenus and $5 \mu \mathrm{g}$ receptor) was transfected into HEK-293T cells using polyethylenimine (Sigma-Aldrich) in a 1:2 ratio in $10-\mathrm{cm}$ dishes. Cells were maintained in culture with Dulbecco's modified Eagle's medium supplemented with $10 \%$ fetal bovine serum and kept in an incubator at $37^{\circ} \mathrm{C}$ and $5 \% \mathrm{CO} 2$. The transfected amount and ratio among the receptor and heterotrimeric $\mathrm{G}$ proteins were tested for optimized dynamic range in drug-induced BRET. HEK-293T were also used in BRET experiments for determination of adenylyl cyclase inhibition (see below). For DMR and ERK1/2 phosphorylation assays, $\mathrm{CHO}$ cells were grown in Minimum Essential Medium (MEMa; Gibco) supplemented with $2 \mathrm{mM} \mathrm{L}$-glutamine, $100 \mu \mathrm{g} / \mathrm{mL}$ sodium pyruvate, MEM nonessential amino acid solution (1/100), 100U/mL penicillin/streptomycin, and 5\% (vol/ vol) of heat-inactivated fetal bovine serum. These cells were transfected with human $a_{2 A^{-}}$ RLuc8 receptor using polyethylenimine in a 1:2 ratio in $25-\mathrm{cm}^{2}$ cell culture flasks. All experiments were performed approximately 48 -hours after transfection.

\section{BRET}

BRET assays were performed to detect receptor ligand-induced events for $\mathrm{Gi} / \mathrm{o}$ protein activation. Gi/o protein activation assay used RLuc-fused Gai/o protein subunit and mVenus-fused $\mathrm{G} \gamma 2$ protein for BRET pair. Receptor and untagged $\mathrm{G} \beta 1$ constructs were cotransfected. As reported previously [19, 20], cells were harvested, washed and resuspended in phosphate-buffered saline. Approximately 200,000 cells/well were distributed in 96-well plates, and $5 \mu \mathrm{M}$ Coelenterazine $\mathrm{H}$ (substrate for luciferase) was added to each well. One 
minute after addition of Coelenterazine $\mathrm{H}$, ligands (DA, NE, clonidine, quinpirole, 7-OHPIPAT, and RO-105824) were added to each well. Antagonists were added 10 minutes before Coelenterazine. The fluorescence of the acceptor was quantified (excitation at $500 \mathrm{~nm}$ and emission at $540 \mathrm{~nm}$ for 1-second recordings) in Mithras LB940 (Berthold Technologies, Bad Wildbad, Germany) to confirm the constant expression levels across experiments. In parallel, the BRET signal from the same batch of cells was determined as the ratio of the light emitted by mVenus $(510-540 \mathrm{~nm}$ ) over that emitted by RLuc $(485 \mathrm{~nm})$. G proteinactivation was calculated as the BRET change (BRET ratio for the corresponding drug minus BRET ratio in the absence of the drug) observed 10 minutes after the addition of the ligands. $E_{\max }$ values were expressed as the percentage of the effect of each ligand over the effect of NE. BRET curves were analyzed by non-linear regression using the commercial Prism 4 (GraphPad Software).

\section{DMR}

A global cell signaling profile or DMR was measured using an EnSpire Multimode Plate Reader (PerkinElmer, Waltham, Massachusetts, US). This label-free approach uses refractive waveguide grating optical biosensors, integrated into 384-well microplates. Changes in local optical density are measured in a detection zone up to $150 \mathrm{~nm}$ above the surface of the sensor. Cellular mass movements induced upon receptor activation are detected by illuminating the underside of the biosensor with polychromatic light and measured as changes in the wavelength of the reflected monochromatic light. These changes are a function of the refraction index. The magnitude of this wavelength shift (in picometers) is directly proportional to the amount of DMR. Briefly, after $24 \mathrm{~h}$ of $\mathrm{CHO}$ cell transfection with $a_{2 A}-R L u c 8$ receptor, cells were resuspended and seeded at a density of 7,000 cells per well in 384-well sensor microplates in $30 \mu \mathrm{l}$ growing media and cultured for $24 \mathrm{~h}$ at $37^{\circ} \mathrm{C}$ and $5 \%$ $\mathrm{CO} 2$, to obtain monolayers at 70\%-80\% confluency. Before starting the assay, cells were washed twice with assay buffer (MEMa supplemented with $20 \mathrm{mM}$ HEPES, $\mathrm{pH} 7.15,0.1 \%$ DMSO and $0.1 \%$ BSA) and incubated $2 \mathrm{~h}$ in $40 \mu \mathrm{l}$ per well in the reader at $24^{\circ} \mathrm{C}$. Hereafter, the sensor plate was scanned, and a baseline optical signature was recorded for $10 \mathrm{~min}$ before adding $10 \mu \mathrm{l}$ of the agonist dissolved in assay buffer and recorded for $90 \mathrm{~min}$. Kinetic results were analyzed using EnSpire Workstation Software v 4.10.

\section{Adenylyl cyclase activity}

BRET assays were performed to detect receptor ligand-induced adenylyl cyclase activity. This assay used the CAMYEL biosensor construct which contains RLuc and YFP. The biosensor detects de conformational changes in Epac that are induced upon its binding to cAMP. The conformational change triggered by an increase in cAMP induced by forskolin results in a decrease in BRET due to the relative orientation change between donor and acceptor. A decrease in forskolin-induced cAMP levels is therefore observed as an increase in BRET [21]. To study Gai dependent inhibition activity, cells were treated as above described but pre-stimulated for 10 minutes with $1 \mu \mathrm{M}$ forskolin (Sigma-Aldrich), in the presence of $10 \mu \mathrm{M}$ propranolol 10 minutes before sample reading to control for activation of endogenous $\beta$ adrenergic receptors (see Results). 


\section{ERK1/2 phosphorylation}

$\mathrm{CHO}$ cells were transfected with $\mathrm{a}_{2 \mathrm{~A}}-\mathrm{RLuc} 8$ receptor, obtaining a transfection of about 0.3 pmols/mg protein. The day of the experiment, cells were starved by treating them with serum free media for $4 \mathrm{~h}$ at $37^{\circ} \mathrm{C}$. After that, cells were incubated with the indicated agonist for 5 minutes at $37^{\circ} \mathrm{C}$. Then, cells were rinsed with ice-cold phosphate-buffered saline and lysed by adding $200 \mathrm{ml}$ ice-cold lysis buffer (50 mM Tris- $\mathrm{HCl}$ [pH 7.4], $50 \mathrm{mM} \mathrm{NaF,} 150$ $\mathrm{mM} \mathrm{NaCl}, 45 \mathrm{mM} \beta$-glycerophosphate, $1 \%$ Triton X-100, $20 \mathrm{mM}$ phenyl-arsine oxide, 0.4 $\mathrm{mM} \mathrm{NaVO}_{4}$, and protease inhibitor cocktail). The cellular debris was removed by centrifugation at $13,000 \mathrm{~g}$ for 5 minutes at $4^{\circ} \mathrm{C}$, and the protein was quantified. To determine the level of ERK1/2 phosphorylation, equivalent amounts of protein were separated by electrophoresis on a denaturing $10 \%$ SDS polyacrylamide gel and transferred onto polyvinylidene fluoride membranes. Odyssey blocking buffer (LI-COR Biosciences, Lincoln, NE) was then added, and the membrane was rocked for 90 minutes. The membranes were then probed with a mixture of a mouse anti- phospho-ERK1/2 antibody (1:2500; Sigma-Aldrich) and rabbit anti-ERK1/2 antibody that recognizes both phosphorylated and nonphosphorylated ERK1/2 (1:40,000; Sigma-Aldrich) overnight at $4^{\circ} \mathrm{C}$. The 42- and 44-kDa bands corresponding to ERK1 and ERK2 were visualized by the addition of a mixture of IRDye 800 (anti-mouse) antibody (1:10,000; Sigma-Aldrich) and IRDye 680 (antirabbit) antibody (1:10,000; Sigma-Aldrich) for 2 hours and scanned by the Odyssey infrared scanner (LICOR Biosciences). Band densities were quantified using the scanner software and exported to Excel (Microsoft, Redmond, WA). The level of phosphorylated ERK1/2 isoforms was normalized for differences in loading using the total ERK1/2 protein band intensities.

\section{Radioligand binding}

Brains of male and female sheep of 4-6 months old were freshly obtained from the local slaughterhouse. Brain tissues (cortex and dorsal striatum) and HEK-293T cell suspensions, were disrupted with a Polytron homogenizer (PTA 20 TS rotor, setting 3; Kinematica, Basel, Switzerland) for two 5 s-periods in 10 volumes of $50 \mathrm{mM}$ Tris-HCl buffer, $\mathrm{pH}$ 7.4, containing a proteinase inhibitor cocktail (Sigma, St. Louis, MO, USA). Membranes were obtained by centrifugation twice at $105.000 \mathrm{~g}$ for $45 \mathrm{~min}$ at $4^{\circ} \mathrm{C}$. The pellet was stored at $-80^{\circ} \mathrm{C}$, washed once more as described above and resuspended in $50 \mathrm{mM}$ Tris-HCl buffer for immediate use. Membrane protein was quantified by the bicinchoninic acid method (Pierce Chemical Co., Rockford, IL, USA) using bovine serum albumin dilutions as standard. Binding experiments were performed with membrane suspensions at room temperature in $50 \mathrm{mM}$ Tris- $\mathrm{HCl}$ buffer, $\mathrm{pH} 7.4$, containing $10 \mathrm{mM} \mathrm{MgCl}_{2}$. For competitionbinding assays, membrane suspensions $(0.2 \mathrm{mg}$ of protein $/ \mathrm{mL})$ were incubated for $2 \mathrm{~h}$ with a constant free concentration of $0.9 \mathrm{nM}$ of the $\mathrm{a}_{2} \mathrm{R}$ antagonist $\left[{ }^{3} \mathrm{H}\right] \mathrm{RX} 821002$, or $1.3 \mathrm{nM}$ of the $\mathrm{D}_{1}$-like receptor antagonist $\left[{ }^{3} \mathrm{H}\right] \mathrm{SCH} 23390$ or $0.8 \mathrm{nM}$ of the $\mathrm{D}_{2}$-like receptor antagonist $\left[{ }^{3} \mathrm{H}\right] \mathrm{YM}-09151-2$ and increasing concentrations of each tested ligand: NE, DA, clonidine, 7OH-PIPAT, quinpirole and RO-105824. For $\mathrm{a}_{2} \mathrm{R}$ saturation-binding assays, membrane suspensions $(0.2 \mathrm{mg}$ of protein $/ \mathrm{mL})$ were incubated for $3 \mathrm{~h}$ at room temperature in $50 \mathrm{mM}$ Tris- $\mathrm{HCl}$ buffer, $\mathrm{pH} 7.4$, containing $10 \mathrm{mM} \mathrm{MgCl}$ with increasing concentrations of the $a_{2} R$ antagonist $\left[{ }^{3} \mathrm{H}\right] \mathrm{RX} 821002$. Non-specific binding was determined in the presence of 10 $\mu \mathrm{M}$ of the non-radiolabeled antagonist RX821002 (for $\mathrm{a}_{2} \mathrm{R}$ ) or $30 \mu \mathrm{M}$ of DA (for D1R and 
$\left.\mathrm{D}_{2} \mathrm{R}\right)$. In all cases, free and membrane-bound ligands were separated by rapid filtration of $500 \mu$ aliquots in a cell harvester (Brandel, Gaithersburg, MD, USA) through Whatman GF/C filters embedded in $0.3 \%$ polyethylenimine that were subsequently washed for $5 \mathrm{~s}$ with $5 \mathrm{ml}$ of ice-cold $50 \mathrm{mM}$ Tris- $\mathrm{HCl}$ buffer. The filters were incubated with $10 \mathrm{~mL}$ of Ecoscint H scintillation cocktail (National Diagnostics, Atlanta, GA, USA) overnight at room temperature and radioactivity counts were determined using a Tri-Carb $2800 \mathrm{TR}$ scintillation counter (PerkinElmer) with an efficiency of $62 \%$.

\section{Binding data analysis}

Data were analyzed according to the 'two-state dimer model' of Casadó et al. [22]. The model assumes GPCR dimers as a main functional unit and provides a more robust analysis of parameters obtained from saturation and competition experiments with orthosteric ligands, as compared with the commonly used 'two-independent-site model' [22, 23]. In saturation experiments with the radioligand, the model analyzes the total number of radioligand binding sites $\left(\mathrm{B}_{\max }\right.$; more specifically it calculates $\mathrm{R}_{\mathrm{T}}$, the total number of dimers, where $B_{\max }=2 R_{T}$ ), the affinity of the radioligand for the first protomer in the unoccupied dimer $\left(\mathrm{K}_{\mathrm{DA} 1}\right)$, the affinity of the radioligand for the second protomer when the first protomer is already occupied by the radioligand $\left(\mathrm{K}_{\mathrm{DA} 2}\right)$ and an index of cooperativity of the radioligand $\left(\mathrm{D}_{\mathrm{CA}}\right)$. A positive or negative value of $\mathrm{D}_{\mathrm{CA}}$ implies either an increase or a decrease in affinity of $\mathrm{K}_{\mathrm{DA} 2}$ versus $\mathrm{K}_{\mathrm{DA} 1}$ and its absolute value provides a measure of the degree of increase or decrease in affinity. In competition experiments the model analyzes the interactions of the radioligand with a competing ligand and it provides the affinity of the competing ligand for the first protomer in the unoccupied dimer $\left(\mathrm{K}_{\mathrm{DB} 1}\right)$, the affinity of the competing ligand for the second protomer when the first protomer is already occupied by the competing ligand $\left(\mathrm{K}_{\mathrm{DB} 2}\right)$ or the radioligand $\left(\mathrm{K}_{\mathrm{DAB}}\right)$ and an index of cooperativity of the competing ligand $\left(\mathrm{D}_{\mathrm{CB}}\right)$. A positive or negative value of $\mathrm{D}_{\mathrm{CB}}$ implies either an increase or a decrease in affinity of $K_{\mathrm{DB} 2}$ versus $\mathrm{K}_{\mathrm{DB} 1}$ and its absolute value provides a measure of the degree of increase or decrease in affinity.

Radioligand competition and saturation curves were analyzed by nonlinear regression using the commercial Grafit curve-fitting software (Erithacus Software, Surrey, UK), by fitting the binding data to the mechanistic two-state dimer receptor model, as described in detail elsewhere [24]. The equation describing the saturation experiment with the radioligand $\mathrm{A}$ in non-cooperative conditions $\left(K_{\mathrm{DA} 2} / \mathrm{K}_{\mathrm{DA} 1}=4\right)$ is: $\mathrm{A}_{\text {bound }}=2 \mathrm{~A} \mathrm{R} \mathrm{R}_{\mathrm{T}} /\left(2 \mathrm{~K}_{\mathrm{DA} 1}+\mathrm{A}\right)$, where $\mathrm{A}$ represents the radioligand concentration. To calculate the macroscopic equilibrium dissociation constants from competition experiments, the following general equation must be applied: $A_{\text {bound }}=\left(\mathrm{K}_{\mathrm{DA} 2} \mathrm{~A}+2 \mathrm{~A}^{2}+\mathrm{K}_{\mathrm{DA} 2} \mathrm{~A} \mathrm{~B} / \mathrm{K}_{\mathrm{DAB}}\right) \mathrm{R}_{\mathrm{T}} /\left(\mathrm{K}_{\mathrm{DA} 1} \mathrm{~K}_{\mathrm{DA} 2}+\mathrm{K}_{\mathrm{DA} 2} \mathrm{~A}+\mathrm{A}^{2}\right.$ $+\mathrm{K}_{\mathrm{DA} 2} \mathrm{~A} \mathrm{~B} / \mathrm{K}_{\mathrm{DAB}}+\mathrm{K}_{\mathrm{DA} 1} \mathrm{~K}_{\mathrm{DA} 2} \mathrm{~B} / \mathrm{K}_{\mathrm{DB} 1}+\mathrm{K}_{\mathrm{D} \text { A1 }} \mathrm{K}_{\mathrm{DA} 2} \mathrm{~B}^{2} /\left(\mathrm{K}_{\mathrm{DB} 1} \mathrm{~K}_{\mathrm{DB} 2}\right)$ ), where B represents the assayed competing compound concentration. F. For A non-cooperative and non-allosteric modulation between $\mathrm{A}$ and $\mathrm{B}$, the equation is simplified due to the fact that $\mathrm{K}_{\mathrm{DA} 2}=4 \mathrm{~K}_{\mathrm{DA} 1}$ and $\mathrm{K}_{\mathrm{DAB}}=2 \mathrm{~K}_{\mathrm{DB} 1} ; \mathrm{A}_{\text {bound }}=\left(4 \mathrm{~K}_{\mathrm{DA} 1} \mathrm{~A}+2 \mathrm{~A}^{2}+2 \mathrm{~K}_{\mathrm{DA} 1} \mathrm{~A} \mathrm{~B} / \mathrm{K}_{\mathrm{DB} 1}\right) \mathrm{R}_{\mathrm{T}} /$ $\left(4 \mathrm{~K}_{\mathrm{DA} 1}{ }^{2}+4 \mathrm{~K}_{\mathrm{DA} 1} \mathrm{~A}+\mathrm{A}^{2}+2 \mathrm{~K}_{\mathrm{DA} 1} \mathrm{~A} \mathrm{~B} / \mathrm{K}_{\mathrm{DB} 1}+4 \mathrm{~K}_{\mathrm{DA} 1}{ }^{2} \mathrm{~B} / \mathrm{K}_{\mathrm{DB} 1}+4 \mathrm{~K}_{\mathrm{DA} 1}{ }^{2} \mathrm{~B}^{2} /\left(\mathrm{K}_{\mathrm{DB} 1}\right.\right.$ $\left.\mathrm{K}_{\mathrm{DB} 2}\right)$ ). For $\mathrm{A}$ and $\mathrm{B}$ non-cooperative and non-allosteric modulation between $\mathrm{A}$ and $\mathrm{B}$, the equation can be simplified due to the fact that: $\mathrm{K}_{\mathrm{DA} 2}=4 \mathrm{~K}_{\mathrm{DA} 1}, \mathrm{~K}_{\mathrm{DB} 2}=4 \mathrm{~K}_{\mathrm{DB} 1}$ and $\mathrm{K}_{\mathrm{DAB}}=$ 


$$
\begin{aligned}
& 2 \mathrm{~K}_{\mathrm{DB} 1} ; \mathrm{A}_{\text {bound }}=\left(4 \mathrm{~K}_{\mathrm{DA} 1} \mathrm{~A}+2 \mathrm{~A}^{2}+2 \mathrm{~K}_{\mathrm{DA} 1} \mathrm{~A} \mathrm{~B} / \mathrm{K}_{\mathrm{DB} 1}\right) \mathrm{R}_{\mathrm{T}} /\left(4 \mathrm{~K}_{\mathrm{DA} 1}{ }^{2}+4 \mathrm{~K}_{\mathrm{DA} 1} \mathrm{~A}+\mathrm{A}^{2}\right. \\
& \left.+2 \mathrm{~K}_{\mathrm{DA} 1} \mathrm{~A} \mathrm{~B} / \mathrm{K}_{\mathrm{DB} 1}+4 \mathrm{~K}_{\mathrm{DA} 1}{ }^{2} \mathrm{~B} / \mathrm{K}_{\mathrm{DB} 1}+\mathrm{K}_{\mathrm{DA} 1} \mathrm{~B}^{2} / \mathrm{K}_{\mathrm{DB} 1}{ }^{2}\right) .
\end{aligned}
$$

\section{Statistical analysis}

In binding assays, goodness of fit was tested according to reduced chi-squared value given by the regression program. The test of significance for two different model population variances was based upon the F-distribution. Using this F-test, a probability greater than $95 \%(\mathrm{p}<0.05)$ was considered the criterion to select a more complex model (cooperativity) over the simplest one (non-cooperativity). In all cases, a probability of less than $70 \%$ ( $p>$ 0.30 ) resulted when one model was not significantly better than the other. In all cases, results are given as parameter values \pm S.E.M. and statistical differences were analyzed with Prism 4.

\section{Drugs}

Dopamine hydrochloride and L-(-)-norepinephrine (+)-bitartrate salt monohydrate were purchased from Sigma. (-) quinpirole hydrochloride, clonidine hydrochloride, 7-OH-PIPAT maleate, RO-105824 dihydrochloride, RX821002 and yohimbine hydrochloride were purchased from Tocris. $\left[{ }^{3} \mathrm{H}\right] \mathrm{RX} 821002(63.9 \mathrm{Ci} / \mathrm{mmol}),\left[{ }^{3} \mathrm{H}\right] \mathrm{SCH} 23390(81.9 \mathrm{Ci} / \mathrm{mmol})$ and $\left[{ }^{3} \mathrm{H}\right] \mathrm{YM}-09151-2$ (84.4 Ci/mmol) were from Perkin-Elmer. Pertussis toxin was purchased from Sigma.

\section{Homology modeling of $a_{2 A}$ and $a_{2 C}$ adrenoceptors}

Homology models of $a_{2 A}$ and $a_{2 C}$ adrenoceptors were constructed from multiple templates using RosettaCM [25] with a protocol previously described [26]. Sequences of each adrenoceptor were aligned with sequences of the following receptors: $\mathrm{D}_{3}$ (PDB ID: 3PBL [27]), $\beta_{1}$ (PDB ID: 4BVN [28]), $\beta_{2}$ (PDB ID: 2RH1 [29]), 5HT $1 \mathrm{~B}$ (PDB ID: 4IAR [30]), and $5 \mathrm{HT}_{2 \mathrm{~B}}$ (PDB ID: 4IB4 [31]) using BLAST and modified to ensure alignment of secondary structure elements and conserved residues (Fig. S1). The N-terminus was truncated through residue 28 and 46 and the C-terminus was deleted after residue 442 and 456, respectively. Additionally, the long intracellular loop 3 was deleted at residues 229-372 in $\mathrm{a}_{2 \mathrm{~A}}$ and 243-381 in $a_{2 C}$ and replaced with an 8-residue poly-Gly linker. These sequences were threaded onto each template and hybridized to generate full length, energy minimized structures. Models were clustered using automatic radius detection in Rosetta and the low energy cluster centers from the top 5 clusters were selected for additional modeling.

\section{Protein-Ligand Docking}

The tridimensional structure of DA was obtained from PubChem (ID 3713609). Conformers of DA were generated using the BCL [32]. To identify the initial starting coordinates for ligand docking, homology models were aligned with the crystal structure of $\beta_{2}$ adrenoceptor (PDB ID: 4LDO (33)) and DA was aligned with the crystallized ligand. Ligand docking was performed in RosettaLigand using the small perturbation of ligand position protocol and swapping of ligand conformers $(34,35) .1000$ models for each protein-ligand complex were generated. Models were sorted initially by total energy and then culled to the top 5\% of 
models by interface energies for analysis. Per-residue $\Delta \Delta \mathrm{G}$ analysis was performed to identify residues involved in ligand binding.

\section{Results}

\section{Binding of DA and DA receptor ligands to $a_{2}$ adrenoceptors in cortical and striatal tissue}

First, we analyzed the ability of NE, DA, the non-selective $a$ adrenoceptor agonist clonidine, the non-selective $\mathrm{D}_{2}-\mathrm{D}_{3}-\mathrm{D}_{4}$ receptor agonist quinpirole, the selective $\mathrm{D}_{3}$ receptor agonist 7OH-PIPAT and the selective $\mathrm{D}_{4}$ receptor agonist RO-105824 to displace the binding of the non-selective $a_{2}$ adrenoceptor antagonist radioligand $\left[{ }^{3} \mathrm{H}\right] \mathrm{RX} 821002$ in membrane preparations from sheep cortex and striatum with competitive inhibition experiments. See Materials and Methods and refs. [22-24] for description of the variables. Saturation experiments with $\left[{ }^{3} \mathrm{H}\right] \mathrm{RX} 821002$ for cortical and striatal tissue provided $\mathrm{B}_{\max }$ values for $\mathrm{a}_{2}$ adrenoceptors of $0.33 \pm 0.02$ and $0.13 \pm 0.02 \mathrm{pmol} / \mathrm{mg}$ protein and affinity values $\left(\mathrm{K}_{\mathrm{DA} 1}\right)$ of $0.06 \pm 0.01$ and $0.07 \pm 0.01 \mathrm{nM}(\mathrm{n}=4-8)$, respectively. This implies that the density of $\mathrm{a}_{2}$ adrenoceptors in the cortex, which is mostly represented by $a_{2 \mathrm{~A}}$ adrenoceptors [3,4], is three times higher than in the striatum, which expresses similar densities for both $a_{2 \mathrm{~A}}$ and $\mathrm{a}_{2 \mathrm{C}}$ adrenoceptors [8]. To test the binding selectivity of $\left[{ }^{3} \mathrm{H}\right] \mathrm{RX} 821002$ for $\mathrm{a}_{2}$ adrenoceptors and not for $\mathrm{D}_{2}$-like receptors, we developed competition experiments of the $\mathrm{D}_{2}$-like receptor antagonist $\left[{ }^{3} \mathrm{H}\right] \mathrm{YM}-09151-2$ with increasing concentrations of unlabeled RX821002 in sheep striatal membranes. RX821002 did not displace the radioligand binding at any concentration up to $10 \mu \mathrm{M}$ (Fig. 1A). The same experiments were also performed in membranes from HEK-293T cells stably transfected with human $D_{2}, D_{3}$ or $D_{4}$ receptors, with identical results (data not shown). These results demonstrate that the radioligand $\left[{ }^{3} \mathrm{H}\right] \mathrm{RX} 821002$ does not bind to $\mathrm{D}_{2}$-like receptors.

Competition experiments of $\left[{ }^{3} \mathrm{H}\right] \mathrm{RX} 821002$ with NE, DA, clonidine and the $\mathrm{D}_{2}$-like receptor ligands in cortical and striatal sheep membranes are shown in Fig. 2A and 2B, respectively, and the $\mathrm{K}_{\mathrm{DB} 1}, \mathrm{~K}_{\mathrm{DB} 2}$ and $\mathrm{D}_{\mathrm{CB}}$ values obtained are presented in Table 1. In both tissues, NE, DA and clonidine showed high affinity for $\left[{ }^{3} \mathrm{H}\right] \mathrm{RX} 821002$ binding sites with an order of potency of clonidine $>$ NE $>$ DA (Fig. 2). The three ligands showed negative cooperativity (negative $\mathrm{D}_{\mathrm{CB}}$ values). The affinity of $\mathrm{NE}$ was higher in the cortex than in the striatum, with higher striatal $\mathrm{K}_{\mathrm{DB} 1}, \mathrm{~K}_{\mathrm{DB} 2}$ and $\mathrm{D}_{\mathrm{CB}}$ values (stronger negative cooperativity) (Table 1). The affinity of DA was very similar in both tissues, with similar $\mathrm{K}_{\mathrm{DB} 1}$ values and a moderately but significantly higher $\mathrm{K}_{\mathrm{DB} 2}$ value in the striatum, resulting in similar $\mathrm{D}_{\mathrm{CB}}$ values (Table 1). The affinity of clonidine was also higher in the cortex, with a significantly higher striatal $\mathrm{K}_{\mathrm{DB} 1}$ value and similar $\mathrm{D}_{\mathrm{CB}}$ values (Table 1). 7-OH-PIPAT and quinpirole also displaced $\left[{ }^{3} \mathrm{H}\right] \mathrm{RX} 821002$ binding with nanomolar and submicromolar affinities, respectively (Table 1 and Fig. 2). Interestingly, 7-OH-PIPAT showed negative cooperativity in the cortex, but not in striatum. The only measurable affinity parameter of 7-OH-PIPAT in the striatum, $\mathrm{K}_{\mathrm{DB} 1}$, was significantly higher than in the cortex and it was almost ten times lower than the cortical $\mathrm{K}_{\mathrm{DB} 2}$ value (Table 1). Quinpirole also showed differences in the binding parameters between the cortex and striatum, such as a lower $\mathrm{K}_{\mathrm{DB} 1}$ value but negative cooperativity in the striatum. Finally, RO-105824 also displaced $\left[{ }^{3} \mathrm{H}\right] \mathrm{RX} 821002$ 
binding from the cortex and striatum with high affinity (subnanomolar). No cooperativity $\left(\mathrm{D}_{\mathrm{CB}}=0\right)$ was obtained, except for RO-105824 in the cortex $\left(\mathrm{D}_{\mathrm{CB}}=-4.3\right)$ (Table 1).

\section{Binding of $D A$ and $N E$ to $D_{1}$-like and $D_{2}$-like receptors in striatal tissue}

Next, we compared the affinity of endogenous DA and NE binding to DA $\mathrm{D}_{1}$-like and $\mathrm{D}_{2}$ like receptors with the affinity, above determined, for $\mathrm{a}_{2}$ adrenoceptors. In addition to competition experiments with the $\mathrm{D}_{2}$-like radioligand antagonist $\left[{ }^{3} \mathrm{H}\right] \mathrm{YM}-09151-2$ (Fig. $1 \mathrm{~A})$, we performed competition experiments with the $\mathrm{D}_{1}$-like radioligand antagonist $\left[{ }^{3} \mathrm{H}\right] \mathrm{SCH} 23390$ in sheep striatal preparations (Fig. 1B). The equilibrium binding parameters are shown in Table 2. Both NE and DA showed negative cooperativity (Fig. 1) with negative $D_{c}$ values (Table 2). The affinity of DA for the first protomer of the $D_{2}$-like receptor dimer $\left(\mathrm{K}_{\mathrm{DB} 1}\right)$, mostly represented by the $\mathrm{D}_{2} \mathrm{R}$ subtype in dorsal striatum (36), was similar to the affinity for $a_{2}$ adrenoceptors and $D_{1}$-like receptors (Fig. 1, Table 2). The affinity of DA for the second protomer $\left(\mathrm{K}_{\mathrm{DB} 2}\right)$ of the $\mathrm{D}_{1}$-like receptor was even about 10 times lower than for $a_{2}$ adrenoceptors and $D_{2}$-like receptors (stronger negative cooperativity; see Table 2). On the other hand, the affinity of NE for $a_{2}$ adrenoceptors in the striatum, represented by $a_{2 A}$ and $a_{2 C}$ adrenoceptors, was significantly higher than for dopamine receptors (Fig. 1). Specifically, NE had an affinity for DA receptors about 60 -fold lower than for $\mathrm{a}_{2}$ adrenoceptors (Table 2 and Fig. 1). We can therefore assume that extracellular physiological levels of DA that are able to activate DA receptors are also able to bind $a_{2}$ adrenoceptors.

\section{$a_{2 A}$ and $a_{2 C}$ adrenoceptor-mediated G protein activation by DA and synthetic DA receptor ligands}

The G protein activation BRET assay (see Materials and Methods) was used to determine the potency and efficacy of the above studied ligands to activate $a$ adrenoceptors in HEK-293T cells transfected with $a_{2 A}$ or $a_{2 C}$ adrenoceptor and one of the five different RLuc-fused Gati/o subunits (Gai1, Gai2, Gai3, Gao1 and Gao2) with Venus-fused G $\gamma 2$ protein as BRET acceptor pair. The amount of Gai/o subunits transfected produced values between 0.5 and 1 million luminescence units (arbitrary units). Previously, we found that luminescence values between 200,000 and 1.5 million did not produce a significant alteration of the $\mathrm{E}_{\max }$ of drug-induced BRET. Moreover, the levels of $a_{2}$ adrenoceptor were around $2 \mathrm{pmol} / \mathrm{mg}$ protein. We also previously reported that, using the same cell line and assay conditions, neither DA or NE produce a significant BRET change when transfected with the same fused $G$ protein subunits but without receptor co-transfection [19]. These transfected receptor levels were only slightly higher than those obtained in binding experiments in sheep brain cortex (see above). A concentration-response of the ligandinduced change in BRET values allows to determine the potency as well as the relative efficacy (to $\mathrm{NE}$ ) at $\mathrm{a}_{2 \mathrm{~A}}$ and $\mathrm{a}_{2 \mathrm{C}}$ adrenoceptor-mediated $\mathrm{G}$ protein activation. Results were largely in agreement with the values obtained with binding experiments, considering that cortical values should represent ligand binding parameters of $a_{2 \mathrm{~A}}$ adrenoceptors, while striatal values represent combined ligand binding parameters for both $a_{2 A}$ and $a_{2 C}$ adrenoceptors. NE was more potent at $a_{2 A}$ than at $a_{2 C}$ adrenoceptor, except for Gai2 and Gai3. On the other hand, DA had similar potencies at both adrenoceptors, except for Gai2 and Gaol. At both $a_{2 A}$ and $a_{2 C}$ adrenoceptors, DA showed high potency and efficacy as compared with NE (Figs. 3 and 4 and Tables 3 and 4), although DA was always less potent 
than NE. The relative DA/NE potency depended on the a adrenoceptor and on the Gai/o subtype (see Table 3). Therefore, the potencies of DA at activating $a_{2 A}$ adrenoceptor varied from about fifteen-fold lower, for Gai1, to about thirty-fold lower, for Gao1. On the other hand, the potencies of DA as compared to $\mathrm{NE}$ at activating $\mathrm{a}_{2 \mathrm{C}}$ adrenoceptor were very close to those of NE and they varied from less than two-fold lower, for Gail, to about seventy-fold lower, for Gai3 (Table 3).

The prototypical non-selective a adrenoceptor agonist clonidine only showed a significantly higher potency at $a_{2 \mathrm{~A}}$ than at $\mathrm{a}_{2 \mathrm{C}}$ adrenoceptors for Gao1 and Gao2 (Table 3). An additional difference as compared to NE was that clonidine behaved as a full agonist at $a_{2 \mathrm{~A}}$ and as a partial agonist at $\mathrm{a}_{2 \mathrm{C}}$ adrenoceptor, except for Gai2 and Gai3 (Figs. 3 and 4 and Table 4). Intriguingly, the level of efficacy of clonidine for $\mathrm{a}_{2 \mathrm{C}}$ adrenoceptor varied significantly with the associated Gai/o protein subtypes, from no decrease for Gai2 to a very significant loss of efficacy for Gao1 (Table 4). Previous studies have already reported a partial agonism of clonidine at $\boldsymbol{a}_{2}$ adrenoceptors, but with disparate results [37, 38], which, at least for $a_{2 C}$, could be related to the Gai/o protein subtypes involved. In summary, the differences in the respective potency values of $\mathrm{NE}$, clonidine and DA for $\mathrm{a}_{2 \mathrm{~A}}$ and $\mathrm{a}_{2 \mathrm{C}}$ adrenoceptors in the $\mathrm{G}$ protein activation BRET experiments, correlates with the higher affinities of NE and clonidine in the cortex and similar affinities of DA in cortex and striatum.

The non-selective $\mathrm{D}_{2}-\mathrm{D}_{3}-\mathrm{D}_{4}$ receptor agonist quinpirole and the selective $\mathrm{D}_{3}$ receptor agonist 7-OH-PIPAT also activated $\mathrm{a}_{2 \mathrm{~A}}$ and $\mathrm{a}_{2 \mathrm{C}}$ adrenoceptors, but with very different profiles (see Figs. 3 and 4 and Tables 3 and 4). 7-OH-PIPAT behaved as a low efficacious agonist at $a_{2 A}$ adrenoceptors for the Gai2 subtype. On the other hand, 7-OH-PIPAT behaved as a partial agonist at $a_{2 C^{-}}$Gail complexes but as a full agonist with the other $a_{2 C^{-}}$ Gai/o complexes. This $\mathrm{D}_{3}$ receptor agonist, at $\mathrm{a}_{2 \mathrm{~A}}$ adrenoceptor, was, in general, as potent as DA and, for both Gao subtypes, was as potent $a_{2 C}$ adrenoceptor agonist as NE. In contrast, quinpirole showed a weak potency (submicromolar range) but also behaved as a partial or full agonist depending on the Gai/o subtype. At $a_{2 \mathrm{~A}}$, quinpirole behaved as a partial agonist for Gi1, Gi2 and Gi3 and full agonist for Go1 and Go2, whereas at $\mathrm{a}_{2 \mathrm{C}}$ it behaved as a partial agonist for all $\mathrm{G}$ protein subtypes except for Gi3 (full agonist) and showed no activity when coupled with Gail. As shown in Fig. 5, yohimbine, a non-selective $a_{2}$ adrenoceptor antagonist, completely blocked the effect of 7-OH-PIPAT and quinpirole at both $a_{2 A}$ and $a_{2 C}$ adrenoceptors (for Gao1), demonstrating the specificity of the $a_{2}$ adrenoceptor signal produced by both agonists. The potency values of 7-OH-PIPAT and quinpirole in $\mathrm{G}$ protein activation BRET experiments correlates with the nanomolar and submicromolar affinities, respectively, seen in binding assays with brain membranes. Moreover, the higher potencies of 7-OH-PIPAT for $a_{2 C}$ versus $a_{2 A}$ adrenoceptors also correlate with our binding results due to the fact that 7-OH-PIPAT showed negative cooperativity in cortex but not in striatum. For quinpirole, however, it would be difficult to establish correlations with results from binding assays due to its low efficacy in BRET assays, which might lead to inaccurate values (Table 3, in parenthesis, and Table 4, in italics). Finally, and unexpectedly, the selective $\mathrm{D}_{4}$ receptor agonist RO-105824 (with subnanomolar affinity for $a$ adrenoceptors) did not produce a significant activation of $a_{2 \mathrm{~A}}$ or $a_{2 C}$ adrenoceptors coupled to any of the Gai/o subtypes, except for a small efficacy at 
$a_{2 A}$ for Gai2 and Gai3 (Figs. 3 and 4). To confirm the binding of this putative selective $\mathrm{D}_{4}$ receptor ligand to $a_{2 A}$ and $a_{2 C}$ adrenoceptors, they were tested for their ability to modify the effect of clonidine. RO-105824 did counteract the respective full and partial agonistic effect of clonidine $(1 \mu \mathrm{M})$ at the $a_{2 A}$ and $a_{2 C}$ adrenoceptors coupled to Gao1 (Fig. 5C-D). Therefore, the results of BRET and radioligand-binding experiments disclosed a previously unknown additional role of the $\mathrm{D}_{4}$ receptor agonist RO-105824, as a very potent and lowefficacious ligand for $\mathrm{a}_{2}$ adrenoceptors at Gai/o activation.

We also determined the effect of DA and synthetic DA receptor ligands on a DMR label-free assay in CHO transfected cells. This approach detects changes in local optical density due to cellular mass movements induced upon receptor activation (see Materials and Methods section), and DMR responses primarily reflect $\mathrm{G}$ protein-dependent signaling in living cells, since it can be abrogated by toxins or inhibitors of the $G$ proteins involved [39]. DA was as capable as NE at activating cellular signaling in $\mathrm{CHO}$ cells transfected with $\mathrm{a}_{2 \mathrm{~A}}$-RLuc8 receptor (Fig. 6A). The amount of $\mathrm{a}_{2 \mathrm{~A}}-\mathrm{RLuc} 8$ receptor expressed was about $0.3 \mathrm{pmol} / \mathrm{mg}$ protein. DA and NE activation decreased by adding the $a_{2 A} \mathrm{R}$ antagonist BRL 44408 indicating the specificity of the cell activation through $\alpha_{2 A}$ receptor. The synthetic DA receptor ligands 7-OH-PIPAT, quinpirole and RO-105824 at $300 \mathrm{nM}$ were also able to produce a significant response (Fig. 6B), substantially lower for RO-105824, which correlates with the G protein activation BRET assays (Fig. 3). These results indicate that DA and synthetic DA receptor ligands are also $a_{2}$ adrenoceptor ligands able to activate Gai/o proteins, which correlate with their efficacy with DMR.

\section{$a_{2 A}$ and $a_{2 C}$ adrenoceptor-mediated effects of NE and DA on adenylyl cyclase activity}

$\mathrm{NE}$ and DA-induced changes in adenylyl cyclase activity were also analyzed by measuring cAMP levels in intact cells transiently transfected with $a_{2 A}$ or $a_{2 C}$ adrenoceptor, using the CAMYEL BRET biosensor (see Materials and Methods section and ref. 21). HEK-293T cells have been reported to endogenously express $\beta$ adrenoceptors [40]. Accordingly, we recently reported that NE, in non-transfected HEK-293T cells, stimulated Gs-mediated cAMP increase, which could be completely inhibited by the selective $\beta$ adrenergic blocker propranolol $(10 \mu \mathrm{M})$ (ref. 19; Suppl. Fig. 1; same website address as above). Therefore, the $\beta$ adrenoceptor antagonist propranolol was added throughout the cAMP detection experiments. As shown in Fig. 7, NE and DA produced an increase in BRET, corresponding to a decrease in forskolin-induced cAMP accumulation for both $\alpha_{2 \mathrm{~A}}$ and $\mathrm{a}_{2 \mathrm{C}}$ adrenoceptortransfected cells. The decrease in adenylyl cyclase activity by NE and DA, provided apparent $\mathrm{EC}_{50}$ values that were qualitatively and quantitatively close to those observed with the Gi/o activation BRET assays, as NE was more potent than DA at $\mathrm{a}_{2 \mathrm{~A}}$ and $\mathrm{a}_{2 \mathrm{C}}(1.4 \pm 0.2$ and $7 \pm 4 \mathrm{nM}$ for NE and $140 \pm 40$ and $90 \pm 20 \mathrm{nM}$ for DA, respectively). The putative Gi/odependent effects mediated by NE and DA were blocked by the non-selective $a_{2}$ adrenoceptor antagonist yohimbine, confirming the receptor specificity of the signal (Fig 7). In addition, cells were treated with pertussis toxin which catalyzes the ADP-ribosylation of the ai subunits of the heterotrimeric $G$ protein preventing its interaction with the receptor. As expected, pertussis toxin treatment selectively eliminated the initial, therefore Gidependent, component of the NE- and DA-mediated effects (Fig. 7). Surprisingly, NE and DA showed inverted U-shaped concentration-response curves with a putative Gs-dependent 
profile at high ligand concentrations for both $\mathrm{a}_{2 \mathrm{~A}}$ and $\mathrm{a}_{2 \mathrm{C}}$ adrenoceptor-transfected cells (Fig. 7). These results could be explained by considering previous studies showing that $a_{2}$ adrenoceptors functionally couple not only to Gi/o proteins but also to Gs [41-45]. Typically, the agonist concentrations necessary to elicit detectable stimulation of adenylyl cyclase are significantly higher than those for inhibition. Equivocal results were published by Zhang et al. [16] when comparing the effect of NE and DA on forskolin-induced adenylyl cyclase activation. In their cell systems, NE seemed to predominantly activate Gs with $\mathrm{a}_{2 \mathrm{~A}}$ and $\mathrm{Gi}$ with $a_{2 C}$, while DA would predominantly activate $\mathrm{Gi}$ with both receptors, but at high micromolar concentrations. In contrast, our experiments show that NE and DA follow the same differential concentration-dependent effects on Gi/o- and Gs- activation and, at least, at 10 and $100 \mu \mathrm{M}, \mathrm{DA}$ and NE promoted Gs activation mediated by both $\mathrm{a}_{2 \mathrm{~A}}$ and $\mathrm{a}_{2 \mathrm{C}}$ adrenoceptors (Fig. 7).

\section{$a_{2 A}$ and $a_{2 C}$ adrenoceptor-mediated effects of NE, DA and synthetic DA receptor ligands on ERK1/2 phosphorylation}

Finally, we studied the ability of DA and synthetic DA receptor ligands to produce MAPK activation. First, we analyzed the increase on ERK1/2 phosphorylation produced by $300 \mathrm{nM}$ of $\mathrm{NE}$ in $\mathrm{CHO}$ cells transfected with $\mathrm{a}_{2 \mathrm{~A}}-\mathrm{RLuc} 8$ receptor. This NE concentration increased ERK1/2 phosphorylation levels 3-fold over basal and this effect was similar to that produced by $1 \mu \mathrm{M}$ of DA (Fig. 8). Next, we demonstrated that the synthetic DA receptor ligands 7OH-PIPAT, quinpirole and RO-105824, at $1 \mu \mathrm{M}$, were also able to produce MAPK activation (Fig. 8). At this concentration, the efficacy of RO-105824 was similar to that of the other ligands. Together with its very low efficacy disclosed on $\mathrm{G}$ protein activation and DMR assays, these results indicate that RO-105824 is a biased agonist of $\mathrm{a}_{2 \mathrm{~A}}$ adrenoceptors with functional selectivity for $\mathrm{G}$ protein-independent signaling. In summary, adenylyl cyclase activity and ERK1/2 phosphorylation experiments confirm the results from radioligandbinding and $\mathrm{G}$ protein activation assays indicating that DA and synthetic DA receptor ligands are efficacious $a_{2}$ adrenoceptor agonists.

\section{Structural basis for DA at $a_{2 A}$ and $a_{2 C}$ adrenoceptors}

An examination of the binding mode of DA to the adrenoceptors was undertaken to model the activity seen in the biological assays. To generate models of $a_{2 \mathrm{~A}}$ and $\mathrm{a}_{2 \mathrm{C}}$ adrenoceptors we used the RosettaCM [25] application within the Rosetta suite of macromolecular modeling tools $[26,46]$. This method relies on optimal alignment of a target sequence with multiple template structures obtained from the PDB which are hybridized together to generate novel models. We submitted the sequence of $a_{2 A}$ and $a_{2 C}$ to BLAST-P and found the top five crystal templates by sequence identity to be the DA $D_{3}$ receptor [27], $\beta_{1}$ adrenoceptor [28], $\beta_{2}$ adrenoceptor [29], serotonin 5- $\mathrm{HT}_{1 \mathrm{~B}}$ receptor [30], and serotonin 5$\mathrm{HT}_{2 \mathrm{~B}}$ receptor [31]. Interestingly, the $\mathrm{a}_{2}$-adrenoceptors have more sequence identity in the transmembrane helical bundle with the $\mathrm{D}_{3}$ receptor than with the related $\beta$-adrenoceptors (Table S1). RosettaCM yielded an ensemble of low-energy models of the receptors, which were clustered by structural similarity. The top five cluster centers were included in the docking studies to account for structural diversity and uncertainty in homology modeling. To understand DA activation, we first examined the binding of DA to the $\mathrm{D}_{3}$ receptor, the only crystal structure of a DA receptor to date. As there is not a co-crystal structure of DA/D 3 
receptor, we first docked DA to the $\mathrm{D}_{3}$ receptor using RosettaLigand [34]. The starting coordinates of epinephrine bound to the $\beta_{2}$ adrenoceptor [33] were used to place DA for docking. Binding pocket analysis identified residue D3.32 interacting with the primary amine in DA and the catechol hydroxyls interacting with S5.42 and S5.46. Important hydrophobic packing against the central portion of DA was achieved by V3.33, H6.55, and F6.51. These are the same interactions that were previously identified in a molecular dynamics simulation of DA binding at $\mathrm{D}_{3}$ receptor [47]. Comparing the residues at these positions to those in $\mathrm{a}_{2 \mathrm{~A}}$ and $\mathrm{a}_{2 \mathrm{C}}$ adrenoceptors revealed identity at all residues except position 6.55 , in which the His has been replaced with a Tyr in both $a_{2 A}$ and $a_{2 C}$ adrenoceptors (Fig. S1). Docking results of DA at either $a_{2 A}$ or $a_{2 C}$ also identified many of these same residues as critical for binding. Particularly D3.32, V3.33, S5.42 and F6.51 were present in all receptor models contributing more than -0.4 Rosetta Energy Units each to the binding of DA (Fig. 9). Residues S5.46 and Y6.55 were also present in all receptor binding modes though contributions varied depending on which receptor type. These results coupled with those from the biological assays provide a strong structural reasoning behind the activity of DA at the $a_{2 \mathrm{~A}}$ or $\mathrm{a}_{2 \mathrm{C}}$ adrenoceptors.

\section{Discussion}

Previous studies reported DA as a potential $a_{2}$ adrenoceptor ligand on the basis of radioligand binding experiments in transfected mammalian and insect cell lines $[16,17]$ and in bird and rat brains (18) and also from autoradiographic experiments in tissues [18].

Furthermore, DA has been reported to decrease cAMP intracellular levels in transfected mammalian cell lines but only throughout $\mathrm{a}_{2 \mathrm{C}}$ adrenoceptors, not $\mathrm{a}_{2 \mathrm{~A}}$ adrenoceptors, and at concentrations much higher than $\mathrm{NE}$ ( $\mathrm{EC}_{50}$ in the micromolar range) [18].

In our study, we show that $a_{2 A}$ and $a_{2 C}$ adrenoceptors can bind DA at concentrations in the same order than NE suggesting that they could be activated by DA at in vivo concentrations. First, our results demonstrate that endogenous DA, and also common synthetic DA-receptor ligands, bind to $a_{2}$ adrenoceptors with moderate to high affinity in the mammalian brain. Second, the affinity of DA for $a_{2}$ adrenoceptors is in the same range as for $D_{1}$-like and $D_{2}$ like receptors, suggesting that endogenous levels of DA can activate both $a_{2}$ adrenoceptors and dopamine receptors. Third, DA and synthetic DA receptor ligands can activate G protein and induce cell DMR through $a_{2}$ adrenoceptors. Finally, DA and NE show the same cell signaling pattern, being both capable to modulate adenylyl cyclase activity and ERK1/2 phosphorylation at nanomolar concentrations.

The most conclusive demonstration that DA is an $a_{2}$ adrenoceptor ligand comes from the results obtained with binding and $\mathrm{G}$ protein activation BRET assays, where the affinities or potencies of DA for $\mathrm{a}_{2}$ adrenoceptors were found to be very similar or even higher than for $\mathrm{D}_{1}$-like and some subtypes of $\mathrm{D}_{2}$-like receptors [19]. Particularly the $\mathrm{EC}_{50}$ values of $\mathrm{DA}$ for $\mathrm{a}_{2 \mathrm{~A}}$ and $\mathrm{a}_{2 \mathrm{C}}$ adrenoceptors (5-170 $\mathrm{nM}$ ) were consistently lower across all Gi/o protein subtypes as compared with the $\mathrm{EC}_{50}$ values $(130-400 \mathrm{nM})$ for the predominant striatal $\mathrm{D}_{2^{-}}$ like receptor $\mathrm{D}_{2 \mathrm{~L}}$ [19]. Taking into account that the levels of tonic extracellular DA are 20-30 nM (with peaks of $500 \mathrm{nM}$ ) [48], DA could reach sufficient extracellular concentration to activate $\mathrm{a}_{2 \mathrm{~A}}$ and $\mathrm{a}_{2 \mathrm{C}}$ adrenoceptors in the striatum, irrespective of the 
maximal concentration of extracellular NE. In fact, striatal DA release sites are designed for transmitter spillover [49] and most striatal DA receptors are primarily extrasynaptic [50, 51], as well as striatal adrenoceptors, based on the mismatched low NE innervation [7-11]. Although the specific functional role of the DA-sensitive $a_{2}$ adrenoceptors in neuronal striatal function remains to be established, a previous study suggests that they might mediate an inhibitory modulatory role of the Gs/olf-coupled striatal adenosine $\mathrm{A}_{2 \mathrm{~A}}$ and $\mathrm{DA} \mathrm{D}_{1}$ receptors [14].

The possibility of DA-mediated activation of $\mathrm{a}_{2 \mathrm{~A}}$ and $\mathrm{a}_{2 \mathrm{C}}$ adrenoceptors in extrastriatal areas should not however, be underestimated. Cortical $a_{2 \mathrm{~A}}$ adrenoceptors are most probably able to be activated by DA, particularly in the prefrontal cortex, which receives a rather dense DA innervation [52]. In fact, there is recent evidence for the localization of $a_{2 A}$ adrenoceptors in the cortical terminals from mesencephalic DA neurons [53], which could play a role as "DA autoreceptors". But there is also evidence for the localization of both $a_{2 A}$ and $\mathrm{a}_{2 \mathrm{C}}$ adrenoceptors in the soma and dendrites of the mesencephalic DA cells of both substantia nigra and ventral tegmental area $[53,54]$. Apart from the NE input, these $a_{2 A}$ and $a_{2 C}$ adrenoceptors should be able to act as "DA autoreceptors" that control the non-synaptic somatodendritic DA release [49]. Adding the present results to our recent study that also indicates a significant role of $\mathrm{NE}$ as a Gi/o-coupled $\mathrm{D}_{2}$-like receptor agonist [19], we could state that Gi/o-coupled adrenoceptors and DA receptors should probably be considered as members of one 'functional' family of catecholamine receptors. A general consideration from the DA and $\mathrm{D}_{2}$-like receptor ligand sensitivity of cortical $\alpha_{2 \mathrm{~A}}$ adrenoceptors is that it should also be involved in the cognitive-enhancing effects associated with their activation, with possible implications for attention deficit hyperactivity disorder [55].

Molecular modeling of DA binding to the various receptors provides a likely binding hypothesis for the results obtained in the biological assays. Of note is the striking similarity between the ligand binding pocket of the $\mathrm{D}_{3}$ receptor and that of $\mathrm{a}_{2 \mathrm{~A}}$ and $\mathrm{a}_{2 \mathrm{C}}$ adrenoceptors. Many of the residues that line the binding pocket are identical or chemically well conserved. Given this similarity it was perhaps unsurprising that the docking of DA at $a_{2 A}$ and $a_{2 C}$ was nearly identical to DA binding to the $D_{3}$ receptor. The lower potency of DA at $a_{2 \mathrm{~A}}$ and $\mathrm{a}_{2 \mathrm{C}}$ adrenoceptors compared to NE seems to depend on a lower number of strong interactions as compared to those between DA and $\mathrm{D}_{3}$ receptors. The pocket may have evolved to bind the slightly bulkier NE and therefore is not of an ideal size for DA. However, the differences may also be due to the lower resolution of binding predictions for a comparative model as opposed to a crystal structure. Despite this, the structural model strongly mimics the results of the binding and activation experiments and therefore provides further evidence of DA acting as a ligand at these receptors.

Another major finding of the present study is that $a_{2 \mathrm{~A}}$ and $\mathrm{a}_{2 \mathrm{C}}$ adrenoceptors are also common targets for compounds previously characterized as $\mathrm{D}_{2}$-like receptor ligands. Particularly striking was the ability of prototypical $\mathrm{D}_{3}$ and $\mathrm{D}_{4}$ receptor agonists 7-OH-PIPAT and RO-105824 to bind with high affinity to $a_{2 A}$ and $a_{2 C}$ adrenoceptors, which might call for revisiting results of previous studies using these compounds. Furthermore, these two compounds and the other DA-synthetic ligands assayed, as well as NE, were able to activate ERK1/2 phosphorylation by binding to $a_{2}$ adrenoceptors. The final pharmacological profile 
of RO-105824 was that of a potent biased agonist for $\mathrm{a}_{2 \mathrm{~A}}$ adrenoceptor with functional selectivity for a $G$ protein-independent signaling. On the other hand, based on BRET experiments, both potency and efficacy dependence on the receptor and the Gai/o protein subtype was the norm for all ligands, including the endogenous neurotransmitters. We already described that NE and DA show different receptor- and Gai/o subtype-dependent potencies of $\mathrm{D}_{2}$-like receptor-mediated $\mathrm{G}$ protein activation [19]. The present results extend these findings to other receptors and to non-endogenous ligands, as well as to differences in efficacy. Even though G proteins of the Gas-Gaolf family do show contrasting brain expression pattern [56], to our knowledge no clear region-specific pattern of mRNA expression for Gai/o protein subtypes has been reported. Detailed characterization of the expression patterns for Gai/o protein subtypes would then be central to determine their role in $a_{2 \mathrm{~A}}$ and $\mathrm{a}_{2 \mathrm{C}}$ adrenoceptor-activation and thus their possible specific targeting with Gai/o subtype functionally selective compounds.

In conclusion, DA is a potent and efficacious ligand at $a_{2}$ adrenoceptors, which modulates forskolin-induced adenylyl cyclase activity and ERK1/2 phosphorylation. The concentration required for these effects is in the range of that for activating $\mathrm{D}_{2}$-like and $\mathrm{D}_{1}$-like receptors, indicating that these receptors are members of one "functional" family of catecholamine receptors. Our results provide a clear answer to the mismatch between the low striatal NE innervation and the high density of striatal $a_{2}$ adrenoceptors, which behave as functional DA receptors.

\section{Acknowledgments}

The authors would like to thank Dr. Céline Galés (INSERM) for generously sharing various Gi-like plasmid constructs for BRET experiments. This research was supported by "Ministerio de Economía y Competitividad" and European Regional Development Funds of the European Union Grant SAF2014-54840-R, "Centro de Investigación Biomédica en Red sobre Enfermedades Neurodegenerativas" Grant CB06/05/0064, the "Fundació La Marató de TV3" Grant 20140610, the fellowship from the Japan Society for the Promotion of Science, and intramural funds of the National Institute on Drug Abuse. Work in the Meiler laboratory is supported through NIH (R01 GM080403, R01 GM099842, R01 DK097376) and NSF (CHE 1305874).

\section{References}

1. Alexander SP, Mathie A, Peters JA. Guide to Receptors and Channels (GRAC), 5th edition. Br J Pharmacol. 2011; 164(1):S1-324. DOI: 10.1111/j.1476-5381.2011.01649_1.x [PubMed: 22040146]

2. MacDonald E, Kobilka BK, Scheinin M. Gene targeting--homing in on alpha 2-adrenoceptorsubtype function. Trends Pharmacol Sci. 1997; 18(6):211-219. [PubMed: 9227000]

3. Nicholas AP, Pieribone V, Hokfelt T. Distributions of mRNAs for alpha-2 adrenergic receptor subtypes in rat brain: an in situ hybridization study. J Comp Neurol. 1993; 328(4):575-594. DOI: 10.1002/cne.903280409 [PubMed: 8381444]

4. Scheinin M, Lomasney JW, Hayden-Hixson DM, Schambra UB, Caron MG, Lefkowitz RJ, Fremeau RT Jr. Distribution of alpha 2-adrenergic receptor subtype gene expression in rat brain. Brain Res Mol Brain Res. 1994; 21(1-2):133-149. [PubMed: 8164514]

5. Fagerholm V, Rokka J, Nyman L, Sallinen J, Tiihonen J, Tupala E, Haaparanta M, Hietala J. Autoradiographic characterization of alpha(2C)-adrenoceptors in the human striatum. Synapse. 2008; 62(7):508-515. DOI: 10.1002/syn.20520 [PubMed: 18435421]

6. Lehto J, Virta JR, Oikonen V, Roivainen A, Luoto P, Arponen E, Helin S, Hietamaki J, Holopainen A, Kailajarvi M, Peltonen JM, Rouru J, Sallinen J, Virtanen K, Volanen I, Scheinin M, Rinne JO. Test-retest reliability of (11)C-ORM-13070 in PET imaging of alpha2C-adrenoceptors in vivo in the 
human brain. Eur J Nucl Med Mol Imaging. 2015; 42(1):120-127. DOI: 10.1007/s00259-014-2899z [PubMed: 25201008]

7. Ordway GA, Jaconetta SM, Halaris AE. Characterization of subtypes of alpha-2 adrenoceptors in the human brain. J Pharmacol Exp Ther. 1993; 264(2):967-976. [PubMed: 8382286]

8. Uhlen S, Lindblom J, Tiger G, Wikberg JE. Quantification of alpha2A and alpha2C adrenoceptors in the rat striatum and in different regions of the spinal cord. Acta Physiol Scand. 1997; 160(4):407412. DOI: 10.1046/j.1365-201X.1997.00175.x [PubMed: 9338523]

9. Lindvall O, Bjorklund A. The organization of the ascending catecholamine neuron systems in the rat brain as revealed by the glyoxylic acid fluorescence method. Acta Physiol Scand Suppl. 1974; 412:1-48. [PubMed: 4531814]

10. Swanson LW, Hartman BK. The central adrenergic system. An immunofluorescence study of the location of cell bodies and their efferent connections in the rat utilizing dopamine-betahydroxylase as a marker. J Comp Neurol. 1975; 163(4):467-505. DOI: 10.1002/cne.901630406 [PubMed: 1100685]

11. Aston-Jones G. Locus coeruleus, A5 and A7 noradrenergic cell groups. In: Paxinos G, editorThe Rat Nervous System. Academic Press; San Diego: 2004. 259-294.

12. Gobert A, Billiras R, Cistarelli L, Millan MJ. Quantification and pharmacological characterization of dialysate levels of noradrenaline in the striatum of freely-moving rats: release from adrenergic terminals and modulation by alpha2-autoreceptors. J Neurosci Methods. 2004; 140(1-2):141-152. DOI: 10.1016/j.jneumeth.2004.04.040 [PubMed: 15589344]

13. Holmberg M, Scheinin M, Kurose H, Miettinen R. Adrenergic alpha2C-receptors reside in rat striatal GABAergic projection neurons: comparison of radioligand binding and immunohistochemistry. Neuroscience. 1999; 93(4):1323-1333. [PubMed: 10501456]

14. Hara M, Fukui R, Hieda E, Kuroiwa M, Bateup HS, Kano T, Greengard P, Nishi A. Role of adrenoceptors in the regulation of dopamine/DARPP-32 signaling in neostriatal neurons. $\mathrm{J}$ Neurochem. 2010; 113(4):1046-1059. DOI: 10.1111/j.1471-4159.2010.06668.x [PubMed: 20236221]

15. Ihalainen JA, Tanila H. In vivo regulation of dopamine and noradrenaline release by alpha2Aadrenoceptors in the mouse nucleus accumbens. J Neurochem. 2004; 91(1):49-56. DOI: 10.1111/j. 1471-4159.2004.02691.x [PubMed: 15379886]

16. Zhang W, Klimek V, Farley JT, Zhu MY, Ordway GA. alpha2C adrenoceptors inhibit adenylyl cyclase in mouse striatum: potential activation by dopamine. J Pharmacol Exp Ther. 1999; 289(3): 1286-1292. [PubMed: 10336518]

17. Alachkar A, Brotchie JM, Jones OT. Binding of dopamine and 3-methoxytyramine as 1-DOPA metabolites to human alpha(2)-adrenergic and dopaminergic receptors. Neurosci Res. 2010; 67(3): 245-249. DOI: 10.1016/j.neures.2010.03.008 [PubMed: 20302892]

18. Cornil CA, Ball GF. Interplay among catecholamine systems: dopamine binds to alpha2-adrenergic receptors in birds and mammals. J Comp Neurol. 2008; 511(5):610-627. DOI: 10.1002/cne.21861 [PubMed: 18924139]

19. Sánchez-Soto M, Bonifazi A, Cai NS, Ellenberger MP, Newman AH, Ferré S, Yano H. Evidence for Noncanonical Neurotransmitter Activation: Norepinephrine as a Dopamine D2-Like Receptor Agonist. Mol Pharmacol. 2016; 89(4):457-466. DOI: 10.1124/mol.115.101808 [PubMed: 26843180]

20. Urizar E, Yano H, Kolster R, Gales C, Lambert N, Javitch JA. CODA-RET reveals functional selectivity as a result of GPCR heteromerization. Nat Chem Biol. 2011; 7(9):624-630. DOI: 10.1038/nchembio.623 [PubMed: 21785426]

21. Jiang LI, Collins J, Davis R, Lin KM, DeCamp D, Roach T, Hsueh R, Rebres RA, Ross EM, Taussig R, Fraser I, Sternweis PC. Use of a cAMP BRET sensor to characterize a novel regulation of cAMP by the sphingosine 1-phosphate/G13 pathway. J Biol Chem. 2007; 282(14):1057610584. DOI: 10.1074/jbc.M609695200 [PubMed: 17283075]

22. Casadó V, Cortés A, Ciruela F, Mallol J, Ferré S, Lluis C, Canela EI, Franco R. Old and new ways to calculate the affinity of agonists and antagonists interacting with G-protein-coupled monomeric and dimeric receptors: the receptor-dimer cooperativity index. Pharmacol Ther. 2007; 116(3):343354. DOI: 10.1016/j.pharmthera.2007.05.010 [PubMed: 17935788] 
23. Ferré S, Casadó V, Devi LA, Filizola M, Jockers R, Lohse MJ, Milligan G, Pin JP, Guitart X. G protein-coupled receptor oligomerization revisited: functional and pharmacological perspectives. Pharmacol Rev. 2014; 66(2):413-434. DOI: 10.1124/pr.113.008052 [PubMed: 24515647]

24. Casadó V, Ferrada C, Bonaventura J, Gracia E, Mallol J, Canela EI, Lluis C, Cortés A, Franco R. Useful pharmacological parameters for G-protein-coupled receptor homodimers obtained from competition experiments. Agonist-antagonist binding modulation. Biochem Pharmacol. 2009; 78(12):1456-1463. DOI: 10.1016/j.bcp.2009.07.012 [PubMed: 19643089]

25. Song Y, DiMaio F, Wang RY, Kim D, Miles C, Brunette T, Thompson J, Baker D. High-resolution comparative modeling with RosettaCM. Structure. 2013; 21(10):1735-1742. DOI: 10.1016/j.str. 2013.08.005 [PubMed: 24035711]

26. Bender BJ, Cisneros A 3rd, Duran AM, Finn JA, Fu D, Lokits AD, Mueller BK, Sangha AK, Sauer MF, Sevy AM, Sliwoski G, Sheehan JH, DiMaio F, Meiler J, Moretti R. Protocols for Molecular Modeling with Rosetta3 and RosettaScripts. Biochemistry. 2016; 55(34):4748-4763. DOI: 10.1021/acs.biochem.6b00444 [PubMed: 27490953]

27. Chien EY, Liu W, Zhao Q, Katritch V, Han GW, Hanson MA, Shi L, Newman AH, Javitch JA, Cherezov V, Stevens RC. Structure of the human dopamine D3 receptor in complex with a D2/D3 selective antagonist. Science. 2010; 330(6007):1091-1095. DOI: 10.1126/science.1197410 [PubMed: 21097933]

28. Miller-Gallacher JL, Nehme R, Warne T, Edwards PC, Schertler GF, Leslie AG, Tate CG. The 2.1 A resolution structure of cyanopindolol-bound beta1-adrenoceptor identifies an intramembrane $\mathrm{Na}$ + ion that stabilises the ligand-free receptor. PLoS One. 2014; 9(3):e92727.doi: 10.1371/ journal.pone.0092727 [PubMed: 24663151]

29. Cherezov V, Rosenbaum DM, Hanson MA, Rasmussen SG, Thian FS, Kobilka TS, Choi HJ, Kuhn P, Weis WI, Kobilka BK, Stevens RC. High-resolution crystal structure of an engineered human beta2-adrenergic G protein-coupled receptor. Science. 2007; 318(5854):1258-1265. DOI: 10.1126/ science.1150577 [PubMed: 17962520]

30. Wang C, Jiang Y, Ma J, Wu H, Wacker D, Katritch V, Han GW, Liu W, Huang XP, Vardy E, McCorvy JD, Gao X, Zhou XE, Melcher K, Zhang C, Bai F, Yang H, Yang L, Jiang H, Roth BL, Cherezov V, Stevens RC, Xu HE. Structural basis for molecular recognition at serotonin receptors. Science. 2013; 340(6132):610-614. DOI: 10.1126/science.1232807 [PubMed: 23519210]

31. Wacker D, Wang C, Katritch V, Han GW, Huang XP, Vardy E, McCorvy JD, Jiang Y, Chu M, Siu FY, Liu W, Xu HE, Cherezov V, Roth BL, Stevens RC. Structural features for functional selectivity at serotonin receptors. Science. 2013; 340(6132):615-619. DOI: 10.1126/science.1232808 [PubMed: 23519215]

32. Kothiwale S, Mendenhall JL, Meiler J. BCL::Conf: small molecule conformational sampling using a knowledge based rotamer library. J Cheminform. 2015; 7:47.doi: 10.1186/s13321-015-0095-1 [PubMed: 26473018]

33. Ring AM, Manglik A, Kruse AC, Enos MD, Weis WI, Garcia KC, Kobilka BK. Adrenalineactivated structure of beta2-adrenoceptor stabilized by an engineered nanobody. Nature. 2013; 502(7472):575-579. DOI: 10.1038/nature12572 [PubMed: 24056936]

34. Meiler J, Baker D. ROSETTALIGAND: protein-small molecule docking with full side-chain flexibility. Proteins. 2006; 65(3):538-548. DOI: 10.1002/prot.21086 [PubMed: 16972285]

35. Lemmon G, Meiler J. Rosetta Ligand docking with flexible XML protocols. Methods Mol Biol. 2012; 819:143-155. DOI: 10.1007/978-1-61779-465-0_10 [PubMed: 22183535]

36. Meador-Woodruff JH, Damask SP, Wang J, Haroutunian V, Davis KL, Watson SJ. Dopamine receptor mRNA expression in human striatum and neocortex. Neuropsychopharmacology. 1996; 15:17-29. [PubMed: 8797188]

37. Pohjanoksa K, Jansson CC, Luomala K, Marjamaki A, Savola JM, Scheinin M. Alpha2adrenoceptor regulation of adenylyl cyclase in $\mathrm{CHO}$ cells: dependence on receptor density, receptor subtype and current activity of adenylyl cyclase. Eur J Pharmacol. 1997; 335(1):53-63. [PubMed: 9371546]

38. Kukkonen JP, Renvaktar A, Shariatmadari R, Akerman KE. Ligand- and subtype-selective coupling of human alpha-2 adrenoceptors to $\mathrm{Ca}++$ elevation in Chinese hamster ovary cells. J Pharmacol Exp Ther. 1998; 287(2):667-671. [PubMed: 9808694] 
39. Schröder R, Schmidt J, Blättermann S, Peters L, Janssen N, Grundmann M, Seemann W, Kaufel D, Merten N, Drewke C, Gomeza J, Milligan G, Mohr K, Kostenis E. Applying label-free dynamic mass redistribution technology to frame signaling of $\mathrm{G}$ protein-coupled receptors noninvasively in living cells. Nat Protoc. 2011; 6(11):1748-1760. DOI: 10.1038/nprot.2011.386 [PubMed: 22015845]

40. Atwood BK, Lopez J, Wager-Miller J, Mackie K, Straiker A. Expression of G protein-coupled receptors and related proteins in HEK293, AtT20, BV2, and N18 cell lines as revealed by microarray analysis. BMC Genomics. 2011; 12:14.doi: 10.1186/1471-2164-12-14 [PubMed: 21214938]

41. Fraser CM, Arakawa S, McCombie WR, Venter JC. Cloning, sequence analysis, and permanent expression of a human alpha 2-adrenergic receptor in Chinese hamster ovary cells. Evidence for independent pathways of receptor coupling to adenylate cyclase attenuation and activation. J Biol Chem. 1989; 264(20):11754-11761. [PubMed: 2568356]

42. Jones SB, Halenda SP, Bylund DB. Alpha 2-adrenergic receptor stimulation of phospholipase A2 and of adenylate cyclase in transfected Chinese hamster ovary cells is mediated by different mechanisms. Mol Pharmacol. 1991; 39(2):239-245. [PubMed: 1847497]

43. Eason MG, Jacinto MT, Liggett SB. Contribution of ligand structure to activation of alpha 2adrenergic receptor subtype coupling to Gs. Mol Pharmacol. 1994; 45(4):696-702. [PubMed: 7910371]

44. Eason MG, Kurose H, Holt BD, Raymond JR, Liggett SB. Simultaneous coupling of alpha 2adrenergic receptors to two G-proteins with opposing effects. Subtype-selective coupling of alpha 2C10, alpha 2C4, and alpha 2C2 adrenergic receptors to Gi and Gs. J Biol Chem. 1992; 267(22): 15795-1580. [PubMed: 1322406]

45. Eason MG, Liggett SB. Identification of a Gs coupling domain in the amino terminus of the third intracellular loop of the alpha 2A-adrenergic receptor. Evidence for distinct structural determinants that confer Gs versus Gi coupling. J Biol Chem. 1995; 270(42):24753-24760. [PubMed: 7559592]

46. Leaver-Fay A, Tyka M, Lewis SM, Lange OF, Thompson J, Jacak R, Kaufman K, Renfrew PD, Smith CA, Sheffler W, Davis IW, Cooper S, Treuille A, Mandell DJ, Richter F, Ban YE, Fleishman SJ, Corn JE, Kim DE, Lyskov S, Berrondo M, Mentzer S, Popovic Z, Havranek JJ, Karanicolas J, Das R, Meiler J, Kortemme T, Gray JJ, Kuhlman B, Baker D, Bradley P. ROSETTA3: an objectoriented software suite for the simulation and design of macromolecules. Methods Enzymol. 2011; 487:545-574. [PubMed: 21187238]

47. Feng Z, Hou T, Li Y. Selectivity and activation of dopamine D3R from molecular dynamics. J Mol Model. 2012; 18(12):5051-5063. DOI: 10.1007/s00894-012-1509-x [PubMed: 22752545]

48. Owesson-White CA, Roitman MF, Sombers LA, Belle AM, Keithley RB, Peele JL, Carelli RM, Wightman RM. Sources contributing to the average extracellular concentration of dopamine in the nucleus accumbens. J Neurochem. 2012; 121(2):252-262. DOI: 10.1111/j. 1471-4159.2012.07677.x [PubMed: 22296263]

49. Rice ME, Patel JC, Cragg SJ. Dopamine release in the basal ganglia. Neuroscience. 2011; 198:112-137. DOI: 10.1016/j.neuroscience.2011.08.066 [PubMed: 21939738]

50. Hersch SM, Ciliax BJ, Gutekunst CA, Rees HD, Heilman CJ, Yung KK, Bolam JP, Ince E, Yi H, Levey AI. Electron microscopic analysis of D1 and D2 dopamine receptor proteins in the dorsal striatum and their synaptic relationships with motor corticostriatal afferents. J Neurosci. 1995; 15(7 Pt 2):5222-5237. DOI: 10.1016/b978-0-12-381270-4.00019-6 [PubMed: 7623147]

51. Yung KK, Bolam JP, Smith AD, Hersch SM, Ciliax BJ, Levey AI. Immunocytochemical localization of D1 and D2 dopamine receptors in the basal ganglia of the rat: light and electron microscopy. Neuroscience. 1995; 65(3):709-730. [PubMed: 7609871]

52. Goldman-Rakic PS, Lidow MS, Smiley JF, Williams MS. The anatomy of dopamine in monkey and human prefrontal cortex. J Neural Transm Suppl. 1992; 36:163-177. [PubMed: 1527516]

53. Castelli MP, Spiga S, Perra A, Madeddu C, Mulas G, Ennas MG, Gessa GL. alpha2A adrenergic receptors highly expressed in mesoprefrontal dopamine neurons. Neuroscience. 2016; 332:130 139. DOI: 10.1016/j.neuroscience.2016.06.037 [PubMed: 27365174]

54. Lee A, Wissekerke AE, Rosin DL, Lynch KR. Localization of alpha2C-adrenergic receptor immunoreactivity in catecholaminergic neurons in the rat central nervous system. Neuroscience. 1998; 84(4):1085-1096. [PubMed: 9578397] 
55. Brennan AR, Arnsten AF. Neuronal mechanisms underlying attention deficit hyperactivity disorder: the influence of arousal on prefrontal cortical function. Ann N Y Acad Sci. 2008; 1129:236-245. DOI: 10.1196/annals.1417.007 [PubMed: 18591484]

56. Herve D. Identification of a specific assembly of the g protein golf as a critical and regulated module of dopamine and adenosine-activated cAMP pathways in the striatum. Front Neuroanat. 2011; 5:48.doi: 10.3389/fnana.2011.00048 [PubMed: 21886607] 
A

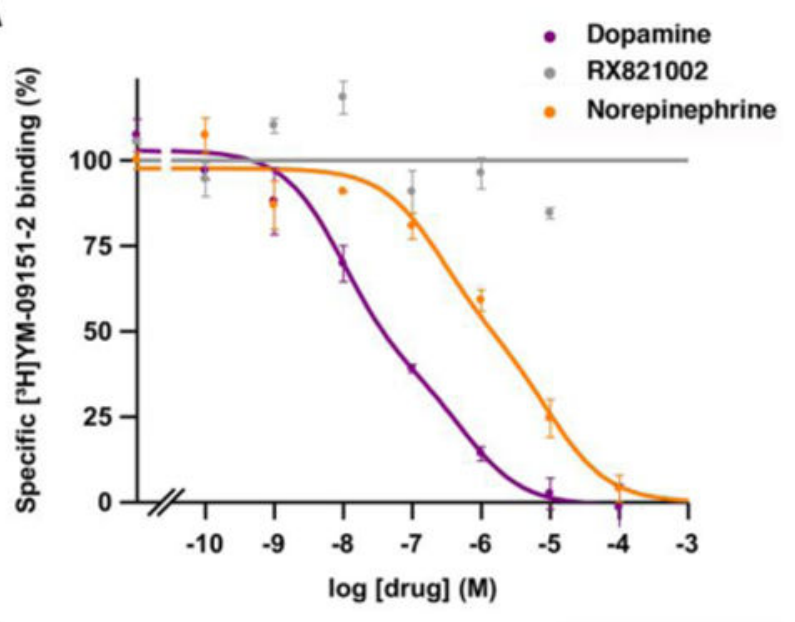

B

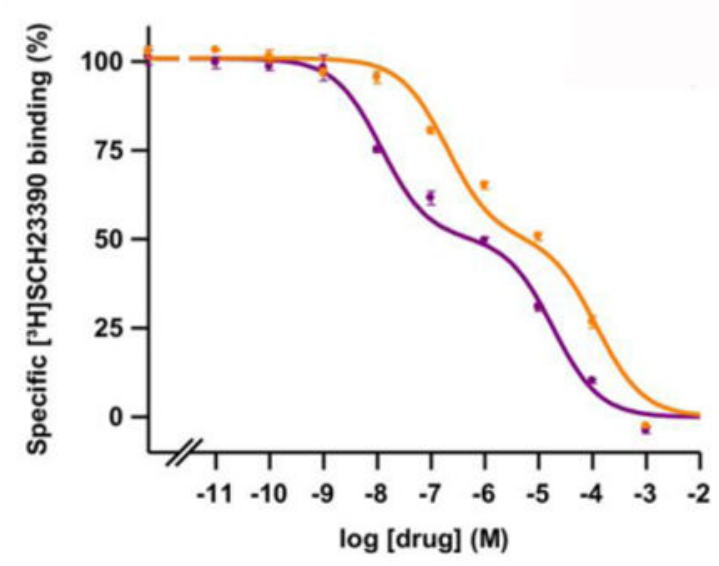

Figure 1. Radioligand binding to $\mathrm{D}_{2}$-like and $\mathrm{D}_{\mathbf{1}}$-like receptors in brain striatum Representative competition curves of $\mathrm{D}_{2}$-like receptor antagonist $\left[{ }^{3} \mathrm{H}\right]-\mathrm{YM}-09151-2$ vs. increasing concentrations of free competitors NE, DA and RX821002 (A) and of $\mathrm{D}_{1}$-like receptor antagonist $\left[{ }^{3} \mathrm{H}\right] \mathrm{SCH} 23390$ vs. increasing concentrations of DA and $\mathrm{NE}(\mathrm{B})$ in sheep brain striatum. Values are expressed as a percentage of the specific binding $(100 \%$ is $0.13 \pm 0.01 \mathrm{pmol} / \mathrm{mg}$ protein in A and $0.43 \pm 0.04 \mathrm{pmol} / \mathrm{mg}$ protein in B). Experimental data were fitted to the two-state dimer receptor model equations, as described in the Materials and Methods section. Values are mean \pm S.E.M. from a representative experiment $(n=3-5)$ performed in triplicate. 

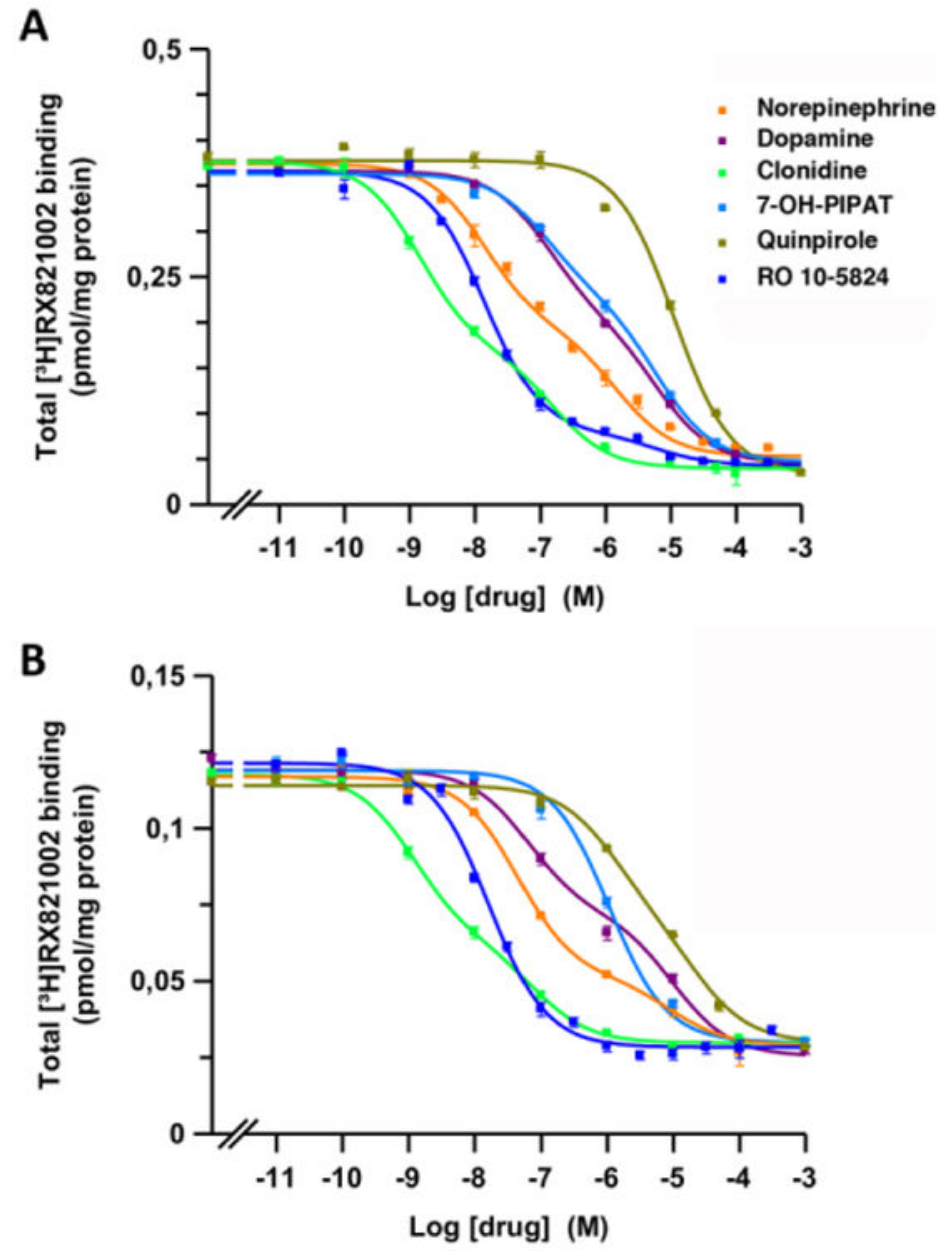

Figure 2. Radioligand binding of dopaminergic and adrenergic ligands to $a_{2}$ adrenoceptors in brain tissue

Representative competition curves of $\mathrm{a}_{2}$ adrenoceptor antagonist $\left[{ }^{3} \mathrm{H}\right] \mathrm{RX} 821002 \mathrm{vs}$. increasing concentrations of free competitors (NE, DA, clonidine, quinpirole, 7-OH-PIPAT and RO-105824) in sheep brain cortical (A) and striatal (B) membranes. Experimental data were fitted to the two-state dimer receptor model equations, as described in the Materials and Methods section. Values are mean \pm S.E.M. from a representative experiment $(n=3)$ performed in triplicate. 

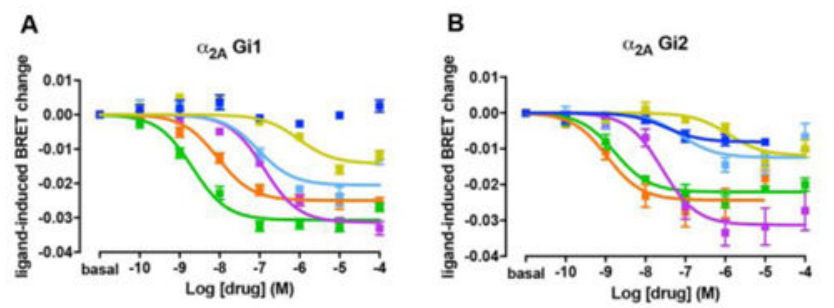

$$
\begin{aligned}
& \text { " Norepinephrine } \\
& \text { " Dopamine } \\
& \text { " Clonidine } \\
& \text { " 7-OH-PIPAT } \\
& \text { " Quinpirole } \\
& \text { - RO 10-5824 }
\end{aligned}
$$
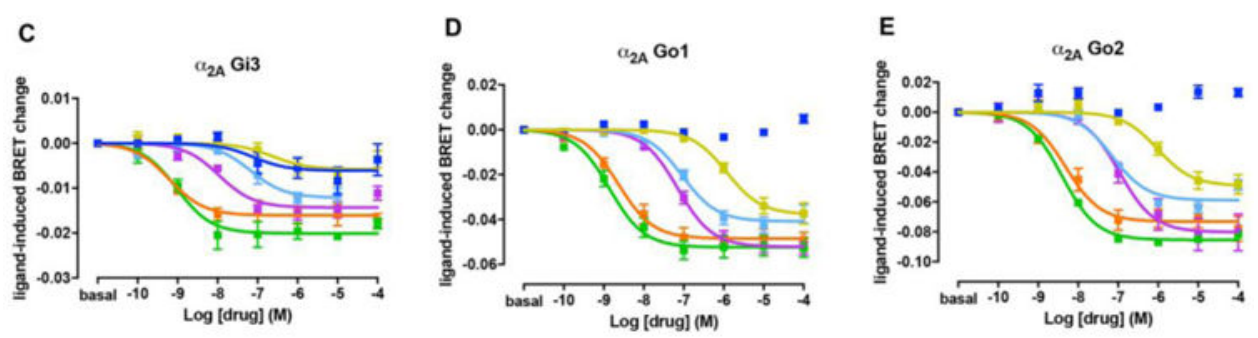

Figure 3. $G$ protein activation of $a_{2 A}$ by dopaminergic and adrenergic ligands Concentration-response experiments of $\mathrm{G}$ protein activation by NE, DA, clonidine and $\mathrm{D}_{2}$ like receptor ligands mediated by $a_{2 A}$ in HEK-293T cells transiently transfected with $a_{2 A}$ adrenoceptor, the G protein subunits Gai1-RLuc (A), Gai2-RLuc (B), Gai3-RLuc (C), Gao1-Rluc (D) or Gao2-RLuc (E), $\gamma 2$-mVenus and non-fused $\beta 1$. Cells were treated with Coelenterazine $\mathrm{H}$ followed by increasing concentrations of one of the ligands. Ligandinduced changes in BRET values were measured as described in the Materials and Methods section. BRET values in the absence of ligands were subtracted from the BRET values for each agonist concentration. Data were adjusted to a sigmoidal concentration-response function by nonlinear regression analysis and represent means \pm S.E.M. of 3 to 11 experiments performed in triplicate (see Table 1 and 2 for $\mathrm{EC}_{50}$ and $\mathrm{E}_{\max }$ values and statistical analysis). 

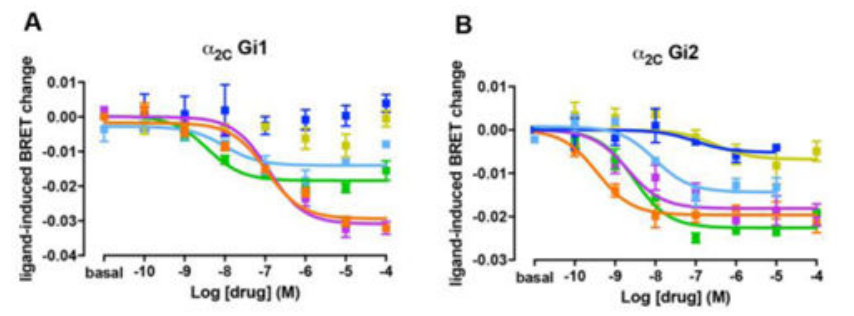

" Norepinephrine

- Dopamine

- Clonidine

- 7-OH-PIPAT

" Quinpirole

- RO 10-5824
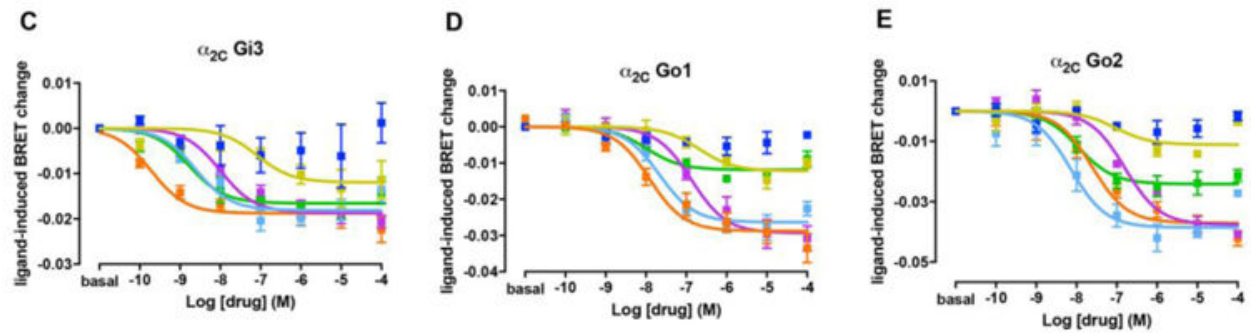

Figure 4. G protein activation of $a_{2 C}$ by dopaminergic and adrenergic ligands Concentration-response experiments of $\mathrm{G}$ protein activation by $\mathrm{NE}, \mathrm{DA}$, clonidine and $\mathrm{D}_{2}$ like receptor ligands mediated by $a_{2 C}$ in HEK-293T cells transiently transfected with $a_{2 C}$ receptor, the G protein subunits Gai1-RLuc (A), Gai2-RLuc (B), Gai3-RLuc (C), Gao1RLuc (D) or Gao2-RLuc (E), $\gamma 2$-mVenus and non-fused $\beta 1$. Cells were treated with Coelenterazine $\mathrm{H}$ followed by increasing concentrations of one of the ligands. Ligandinduced changes in BRET values were measured as described in the Materials and Methods section. BRET values in the absence of ligands were subtracted from the BRET values for each agonist concentration. Data were adjusted to a sigmoidal concentration-response function by nonlinear regression analysis and represent means \pm S.E.M. of 3 to 9 experiments performed in triplicate (see Table 1 and 2 for $\mathrm{EC}_{50}$ and $\mathrm{E}_{\max }$ values and statistical analysis). 

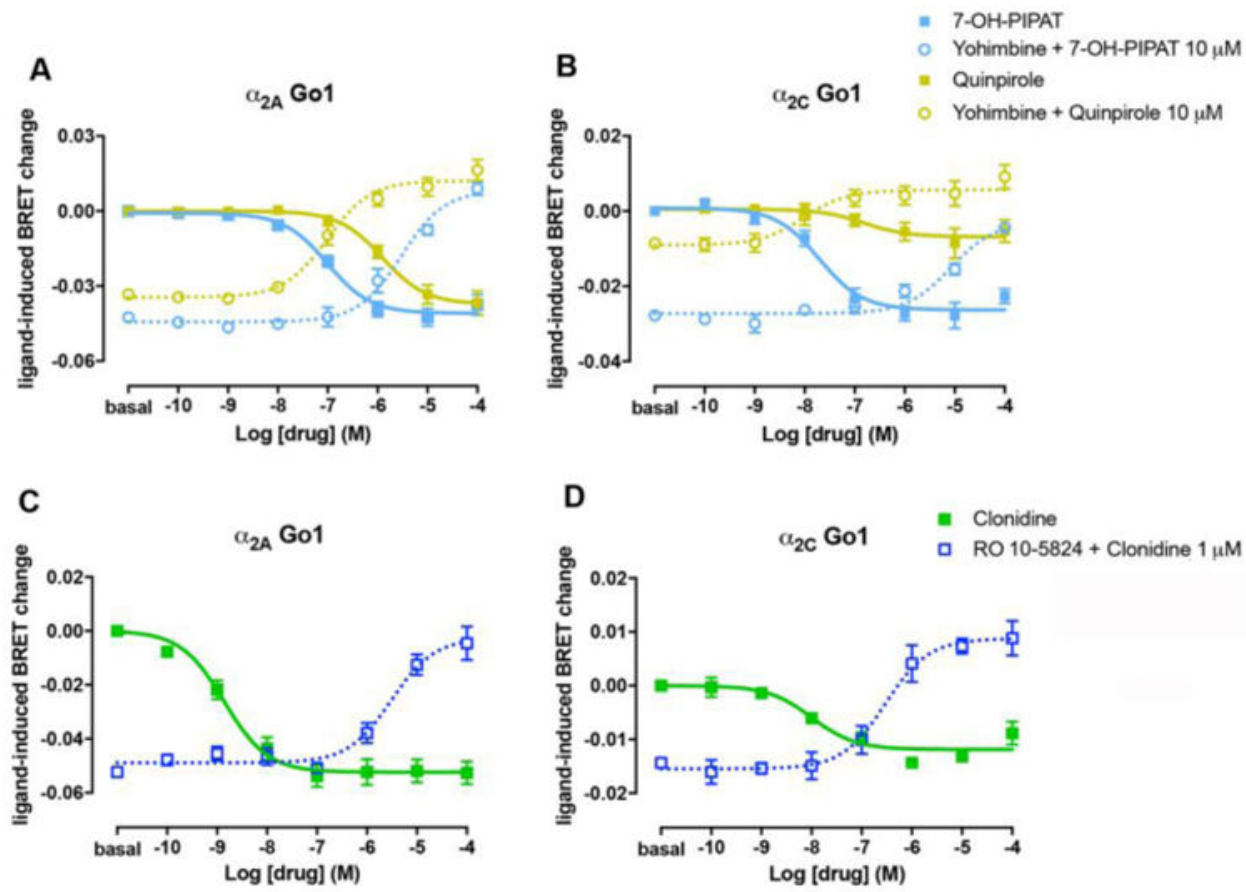

Figure 5. Specificity of the effect of dopaminergic ligands on $a_{2 \mathrm{~A}}$ and $a_{2 \mathrm{C}}$ adrenoceptors (A, B) Dose-dependent inhibition by increasing concentrations of the non-selective $a_{2}$ receptor antagonist yohimbine of Gaol protein activation induced by $10 \mu \mathrm{M}$ of the $\mathrm{D}_{2}$-like receptor agonists 7-OH-PIPAT (dotted blue) or $10 \mu \mathrm{M}$ of quinpirole (dotted yellow) in HEK-293T cells transfected with $a_{2 A}(A)$ or $a_{2 C}(B)$ adrenoceptors, Gao1-RLuc, $\gamma_{2}-$ mVenus and non-fused $\beta_{1}$. As controls, concentration-response curves of Gaol protein activation by 7-OH-PIPAT (full blue) or quinpirole (full yellow) from Fig. 3D and Fig. 4D are showed. Cells were treated with Coelenterazine $\mathrm{H}$ followed by the addition of 7-OHPIPAT or quinpirole. Ligand-induced changes in BRET values were measured as described in the Materials and Methods section. (C, D) Dose-dependent inhibition of the agonistic effect of clonidine at $1 \mu \mathrm{M}$ by increasing concentrations of RO-105824 (dark blue) in cells transfected with $a_{2 A}(C)$ or $a_{2 C}(D)$ adrenoceptors, Gao1-RLuc, $\gamma_{2}$-mVenus and non-fused $\beta_{1}$. As controls, concentration-response curves of Gao1 protein activation by clonidine (full green) from Fig. 3D and Fig. 4D are showed. Data were adjusted to a sigmoidal concentration-response function by nonlinear regression analysis and represent means \pm S.E.M. of 3 to 6 experiments performed in triplicate. 

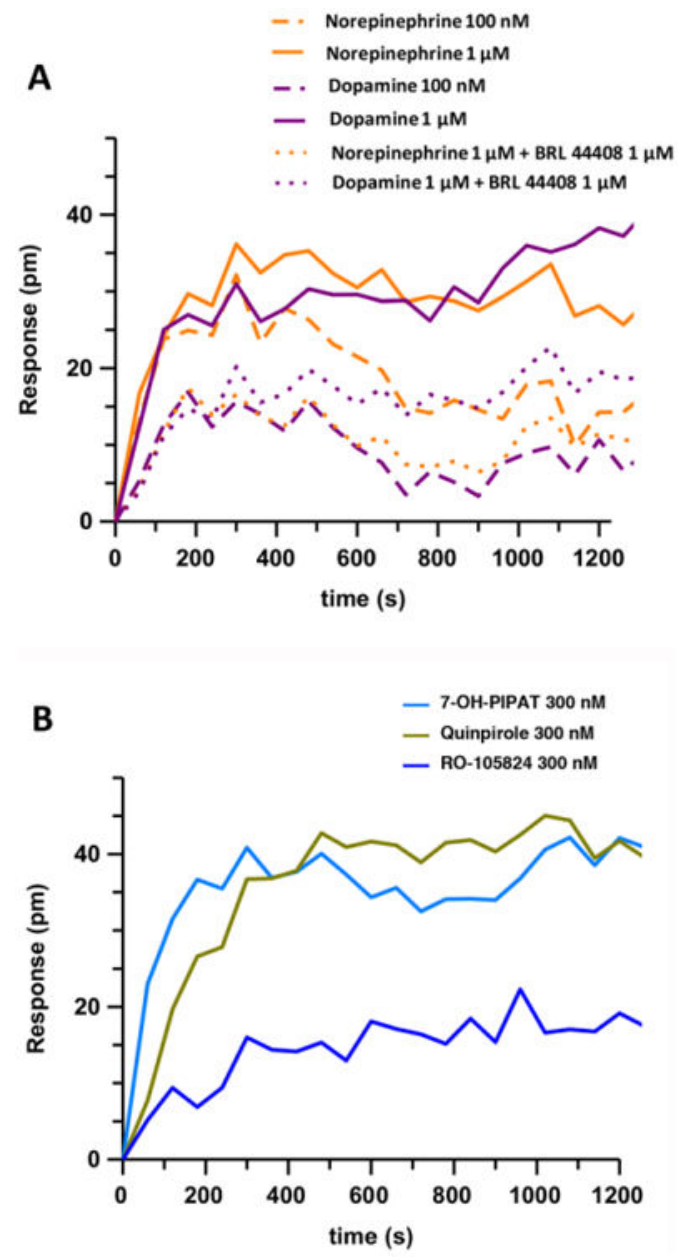

Figure 6. DMR induced by NE, DA and synthetic DA receptor ligands using label-free assay DMR assay was performed in $\mathrm{CHO}$ cells transfected with $\mathrm{a}_{2 \mathrm{~A}}$ adrenoceptor. (A) Cells were pretreated (dotted lines) or not (full lines) with the $\mathrm{a}_{2 \mathrm{~A}}$ adrenoceptor antagonist BRL 44408 at $1 \mu \mathrm{M}$ for 30 minutes before adding the endogenous agonists DA or $\mathrm{NE}$ at $300 \mathrm{nM}$ or 1 $\mu \mathrm{M}$. (B) Cells were treated with $100 \mathrm{nM}$ of several synthetic DA receptor ligands. The resulting shifts of reflected light wavelength $(\mathrm{pm})$ were monitored over time. Each panel is a representative experiment of $n=3$ different experiments. Each curve is the mean of a representative optical trace experiment carried out in triplicates. 
A

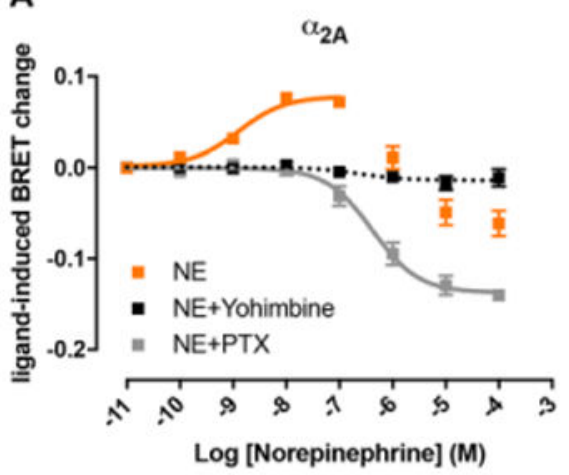

C

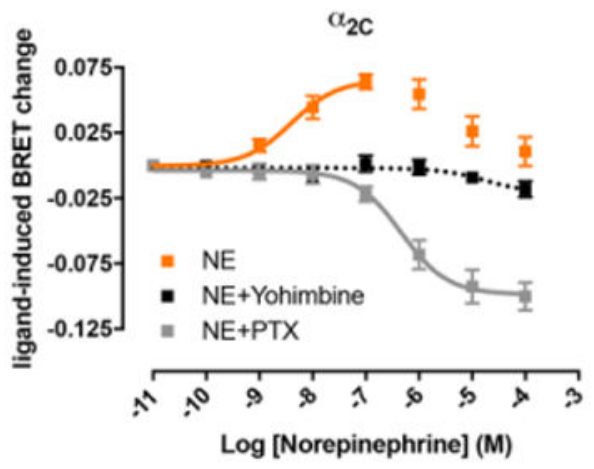

B

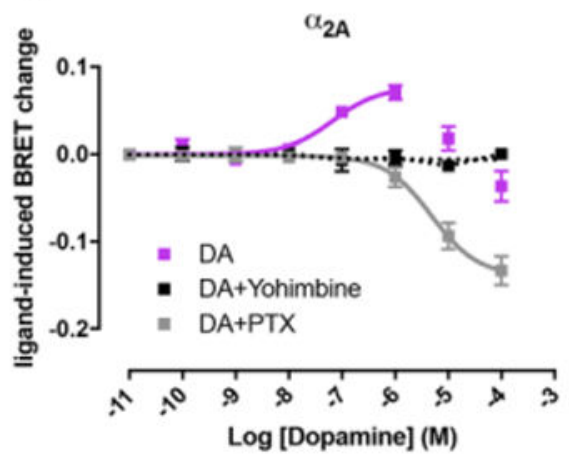

D

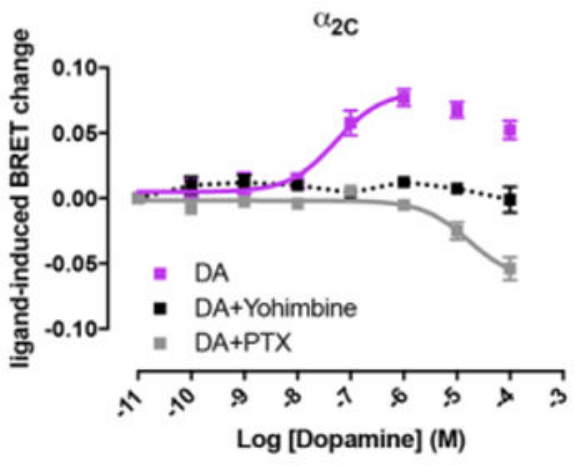

Figure 7. Effect of NE and DA on the modulation of adenylyl cyclase activity by activation of $a_{2 \mathrm{~A}}$ and $a_{2 \mathrm{C}}$ adrenoceptors

Concentration-response experiments of inhibition of forskolin-induced adenylyl cyclase activity by NE (orange) or DA (purple) mediated by $a_{2 A}$ (A, B) or $a_{2 C}$ adrenoceptors (C, D) in HEK-293T cells transiently transfected with the CAMYEL sensor and one of the receptors. Cells were treated with forskolin $(1 \mu \mathrm{M})$ for 10 minutes with or without the selective $\alpha_{2}$ antagonist yohimbine $(10 \mu \mathrm{M})$ followed by the addition of Coelenterazine $\mathrm{H}$ and increasing concentrations of NE or DA. After 10 minutes, BRET was measured as described in the Materials and Methods section. In grey, cells were treated with $100 \mathrm{ng} / \mathrm{ml}$ pertussis toxin (PTX) for 16-18 h previous to the experiment. Values obtained with forskolin alone were subtracted from BRET values for each agonist concentration. Data represent the mean \pm S.E.M. of 3 to 7 experiments performed in triplicate. 
A

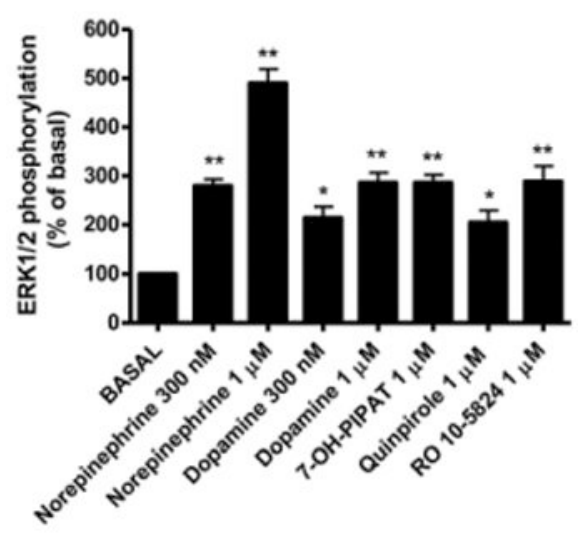

B

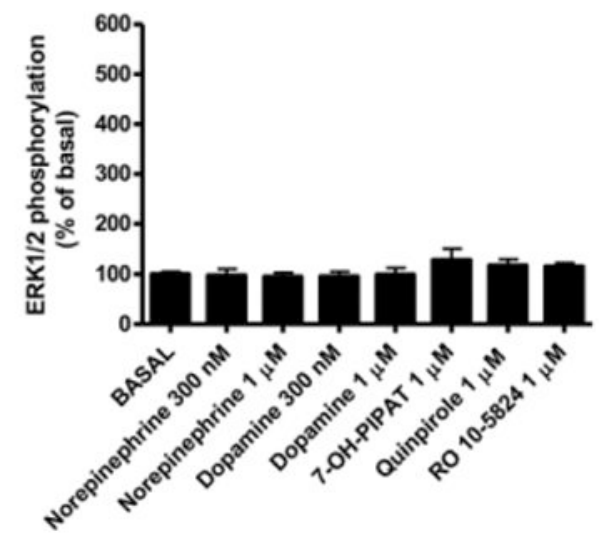

Figure 8. NE, DA and synthetic DA receptor ligands signaling via ERK 1/2 phosphorylation ERK 1/2 phosphorylation was determined in CHO cells transfected with the $a_{2 \mathrm{~A}}$ adrenoceptor (A) and non-transfected control cells (B), treated with $300 \mathrm{nM}$ or $1 \mu \mathrm{M}$ of the tested ligands for 5 minutes at $37^{\circ}$ C. Values are expressed as mean \pm S.E.M. $(n=6)$ of percentage of phosphorylation relative to basal levels in not treated cells. Statistical differences vs. basal conditions were calculated by one-way ANOVA followed by Dunnett's post hoc test; $* \mathrm{p}<0.05$ and $* * \mathrm{p}<0.01$. 

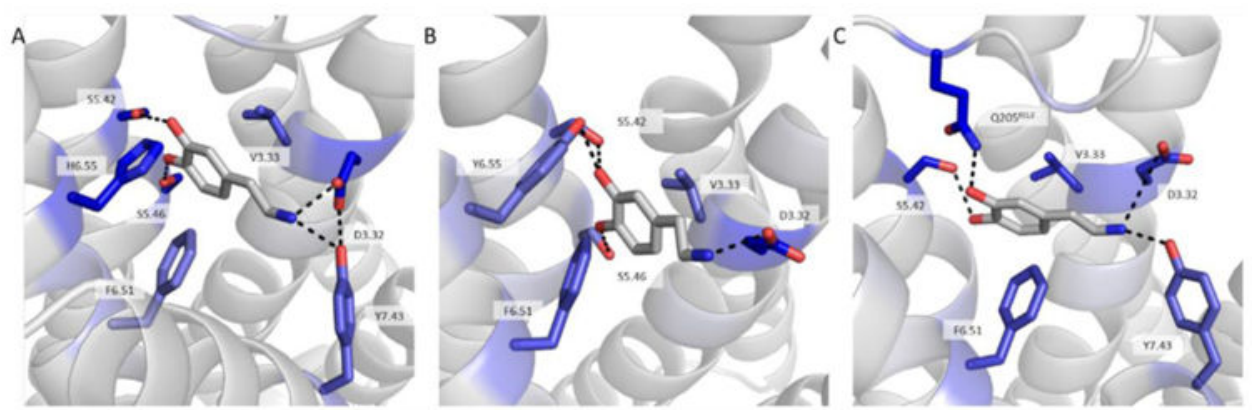

Figure 9. Binding mode of $\mathrm{DA}$ at each receptor type

Shown is the docking orientation of DA at the $\mathrm{D}_{3}$ receptor $(\mathrm{A})$ and $\mathrm{a}_{2 \mathrm{~A}}(\mathrm{~B})$, and $\mathrm{a}_{2 \mathrm{C}}$ adrenoceptors (C). Residues were scored for binding energy $\Delta \Delta \mathrm{G}$ and those most strongly contributing to the binding of DA are shown in stick representation. The strength of binding interaction is colored by the depth of blue with dark blue being the most strongly contributing. Important hydrogen bonds to the amine group and catechol hydroxyls are formed in all binding poses. 
Table 1

Competitive inhibition experiments of $\left[{ }^{3} \mathrm{H}\right] \mathrm{RX821002}$ versus $\mathrm{NE}$, DA, clonidine and $\mathrm{D}_{2}$ like receptor ligands in sheep brain cortex and striatum

\begin{tabular}{|c|c|c|}
\hline \multirow[t]{2}{*}{$\overline{\text { LIGAND }}$} & \multicolumn{2}{|c|}{ BINDING PARAMETERS } \\
\hline & CORTEX & STRIATUM \\
\hline \multirow{3}{*}{$\mathbf{N E}$} & $\mathrm{K}_{\mathrm{DB} 1}: 0.3 \pm 0.2^{*}$ & $\mathrm{~K}_{\mathrm{DB} 1}: 0.8 \pm 0,1$ \\
\hline & $\mathrm{K}_{\mathrm{DB} 2}: 250 \pm 100$ & $\mathrm{~K}_{\mathrm{DB} 2}: 5000 \pm 3000$ \\
\hline & $\mathrm{D}_{\mathrm{CB}}:-2.3$ & $\mathrm{D}_{\mathrm{CB}}:-3.2$ \\
\hline \multirow{3}{*}{ DA } & $\mathrm{K}_{\mathrm{DB} 1}: 6.9 \pm 0.2$ & $\mathrm{~K}_{\mathrm{DB} 1}: 6 \pm 1$ \\
\hline & $\mathrm{K}_{\mathrm{DB} 2}: 350 \pm 10^{*}$ & $\mathrm{~K}_{\mathrm{DB} 2}: 1000 \pm 200$ \\
\hline & $\mathrm{D}_{\mathrm{CB}}:-1.1$ & $\mathrm{D}_{\mathrm{CB}}:-1.6$ \\
\hline \multirow{3}{*}{ Clonidine } & $\mathrm{K}_{\mathrm{DB} 1}: 0.014 \pm 0.003 *$ & $\mathrm{~K}_{\mathrm{DB} 1}: 0.036 \pm 0.005$ \\
\hline & $\mathrm{K}_{\mathrm{DB} 2}: 40 \pm 20$ & $\mathrm{~K}_{\mathrm{DB} 2}: 20 \pm 10$ \\
\hline & $\mathrm{D}_{\mathrm{CB}}:-2.8$ & $\mathrm{D}_{\mathrm{CB}}:-2.1$ \\
\hline \multirow{3}{*}{ 7-OH-PIPAT } & $\mathrm{K}_{\mathrm{DB} 1}: 9 \pm 2 * *$ & $\mathrm{~K}_{\mathrm{DB} 1}: 51 \pm 6$ \\
\hline & $\mathrm{K}_{\mathrm{DB} 2}: 430 \pm 80$ & \\
\hline & $\mathrm{D}_{\mathrm{CB}}:-1.1$ & $\mathrm{D}_{\mathrm{CB}}: 0$ \\
\hline \multirow{3}{*}{ Quinpirole } & $\mathrm{K}_{\mathrm{DB} 1}: 530 \pm 50 * *$ & $\mathrm{~K}_{\mathrm{DB} 1}: 110 \pm 10$ \\
\hline & & $\mathrm{K}_{\mathrm{DB} 2}: 2700 \pm 400$ \\
\hline & $\mathrm{D}_{\mathrm{CB}}: 0$ & $\mathrm{D}_{\mathrm{CB}}:-0.8$ \\
\hline \multirow{3}{*}{ RO-105824 } & $\mathrm{K}_{\mathrm{DB} 1}: 0.055 \pm 0.003^{* * *}$ & $\mathrm{~K}_{\mathrm{DB} 1}: 0.42 \pm 0.03$ \\
\hline & $\mathrm{K}_{\mathrm{DB} 2}: 4000 \pm 2000$ & \\
\hline & $\mathrm{D}_{\mathrm{CB}}:-4.3$ & $\mathrm{D}_{\mathrm{CB}}: 0$ \\
\hline
\end{tabular}

Binding parameters from competitive-inhibition experiments of $\left[{ }^{3} \mathrm{H}\right] \mathrm{RX} 821002$ versus $\mathrm{NE}$, DA, clonidine and $\mathrm{D} 2$-like receptor ligands in membrane preparations from sheep brain cortex and striatum (Fig. 2). KDB1, KDB2 and DCB values were obtained according to the two-state dimer model (see Materials and Methods and ref. 22). $\mathrm{K}_{\mathrm{DB} 1}$ and $\mathrm{K}_{\mathrm{DB} 2}$ (in $\mathrm{nM}$ ) are expressed as means \pm S.E.M. of 3 experiments performed in triplicate. Statistical differences between affinity parameters of cortical versus striatal adrenoceptors were calculated by non-paired, two-tailed Student's t test;

p $<0.05$,

**

$\mathrm{p}<0.01$ and

*** $<0.001$. 
Table 2

Competitive inhibition experiments of $\left[{ }^{3} \mathrm{H}\right] \mathrm{SCH} 23390,\left[{ }^{3} \mathrm{H}\right] \mathrm{YM}-09151-2$ or

$\left.{ }^{3} \mathrm{H}\right] \mathrm{RX821002}$ versus $\mathrm{DA}$ and $\mathrm{NE}$ in sheep brain striatum

\begin{tabular}{lll}
\hline RECEPTOR & \multicolumn{2}{c}{ BINDING PARAMETERS } \\
\hline & DA & NE \\
\hline & $\mathrm{K}_{\mathrm{DB} 1}: 8 \pm 3$ & $\mathrm{~K}_{\mathrm{DB} 1}: 53 \pm 90^{\# \#}$ \\
D 1 -like $^{\#}$ & $\mathrm{~K}_{\mathrm{DB} 2}: 8000 \pm 1000^{* * * *}$ & $\mathrm{~K}_{\mathrm{DB} 2}: 50000 \pm 10000^{\#}$ \\
& $\mathrm{D}_{\mathrm{c}}:-2.4$ & $\mathrm{D}_{\mathrm{c}}:-2.4$ \\
\hline & $\mathrm{K}_{\mathrm{DB} 1}: 3.5 \pm 0.6$ & $\mathrm{~K}_{\mathrm{DB} 1}: 60 \pm 40^{\# \#}$ \\
& $\mathrm{~K}_{\mathrm{DB} 2}: 700 \pm 200$ & $\mathrm{~K}_{\mathrm{DB} 2}: 3400 \pm 100$ \\
& $\mathrm{D}_{\mathrm{c}}:-1.7$ & $\mathrm{D}_{\mathrm{c}}:-1.2$ \\
\hline & $\mathrm{K}_{\mathrm{DB} 1}: 6 \pm 1$ & $\mathrm{~K}_{\mathrm{DB} 1}: 0.8 \pm 0.1$ \\
$\boldsymbol{a}_{2}$ & $\mathrm{~K}_{\mathrm{DB} 2}: 1000 \pm 200$ & $\mathrm{~K}_{\mathrm{DB} 2}: 5000 \pm 3000$ \\
& $\mathrm{D}_{\mathrm{c}}:-1.6$ & $\mathrm{D}_{\mathrm{c}}:-3.2$ \\
\hline
\end{tabular}

Binding parameters from competitive-inhibition experiments of $\left[{ }^{3} \mathrm{H}\right] \mathrm{SCH} 23390$ (D1-like receptor antagonist), $\left[{ }^{3} \mathrm{H}\right] \mathrm{YM}-09151-2$ (D2-like receptor antagonist) or $\left[{ }^{3} \mathrm{H}\right] \mathrm{RX} 821002$ ( $\mathrm{a}_{2}$ receptor antagonist), versus $\mathrm{NE}$ and DA in sheep brain striatum. $\mathrm{K}_{\mathrm{DB} 1}, \mathrm{~K}_{\mathrm{DB}} 2$ and $\mathrm{D}_{\mathrm{c}}$ values were obtained according to the two-state dimer model (see Materials and Methods and ref. 22). Values for a 2- adrenoceptors are from Table 1. KDB1 and KDB2 (in $\mathrm{nM}$ ) are expressed as means \pm S.E.M. of 3-5 experiments performed in triplicate. Statistical differences between affinity parameters obtained were calculated by one-way ANOVA followed by Dunnett's post hoc test; for DA,

***

p $<0.001$ vs. D2-like receptors; for NE,

${ }_{\mathrm{p}}^{\#}<0.05$ and

$\#$ p $<0.01$ vs. a 2 receptors. 


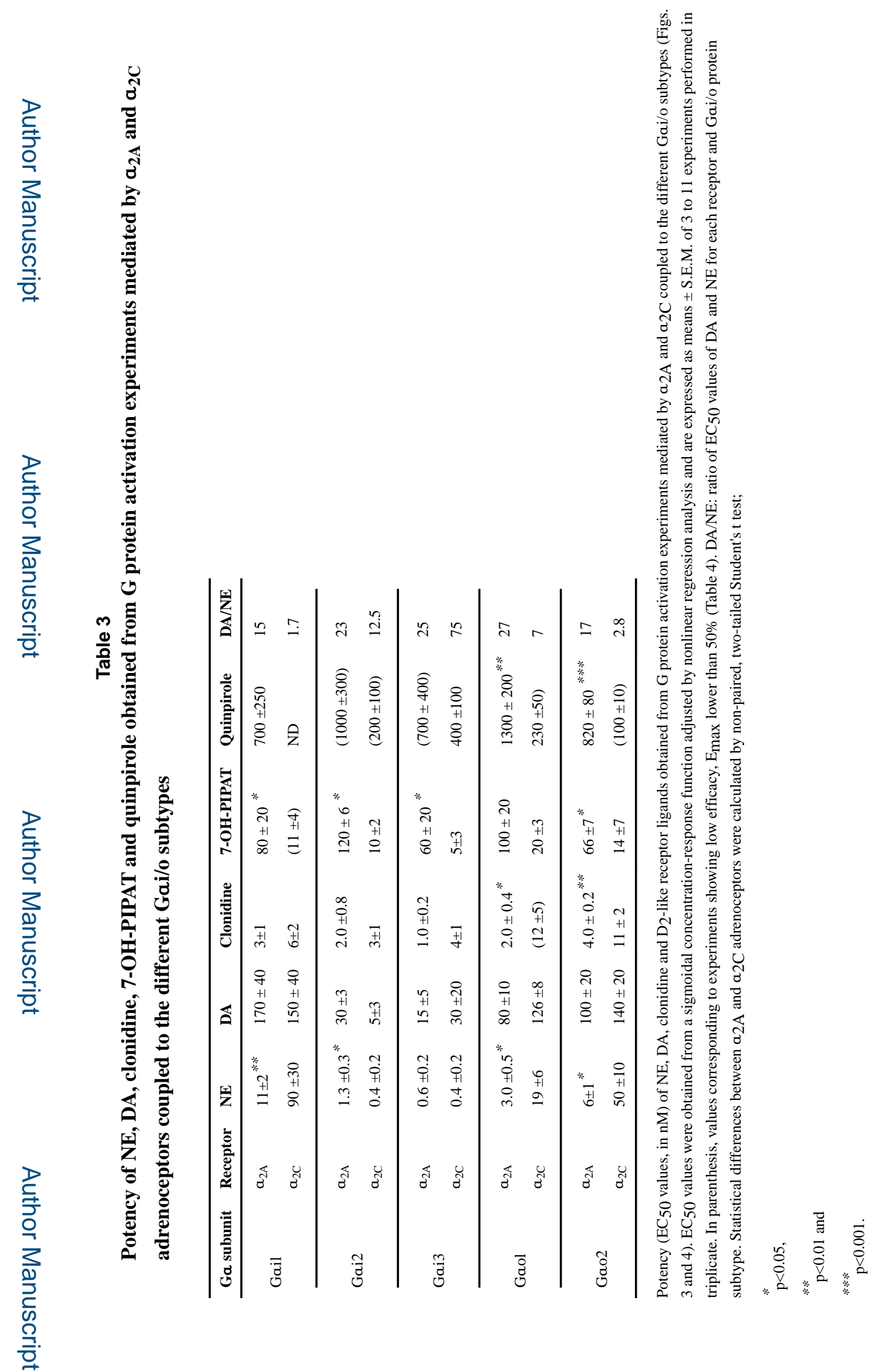

Mol Neurobiol. Author manuscript; available in PMC 2019 November 01. 


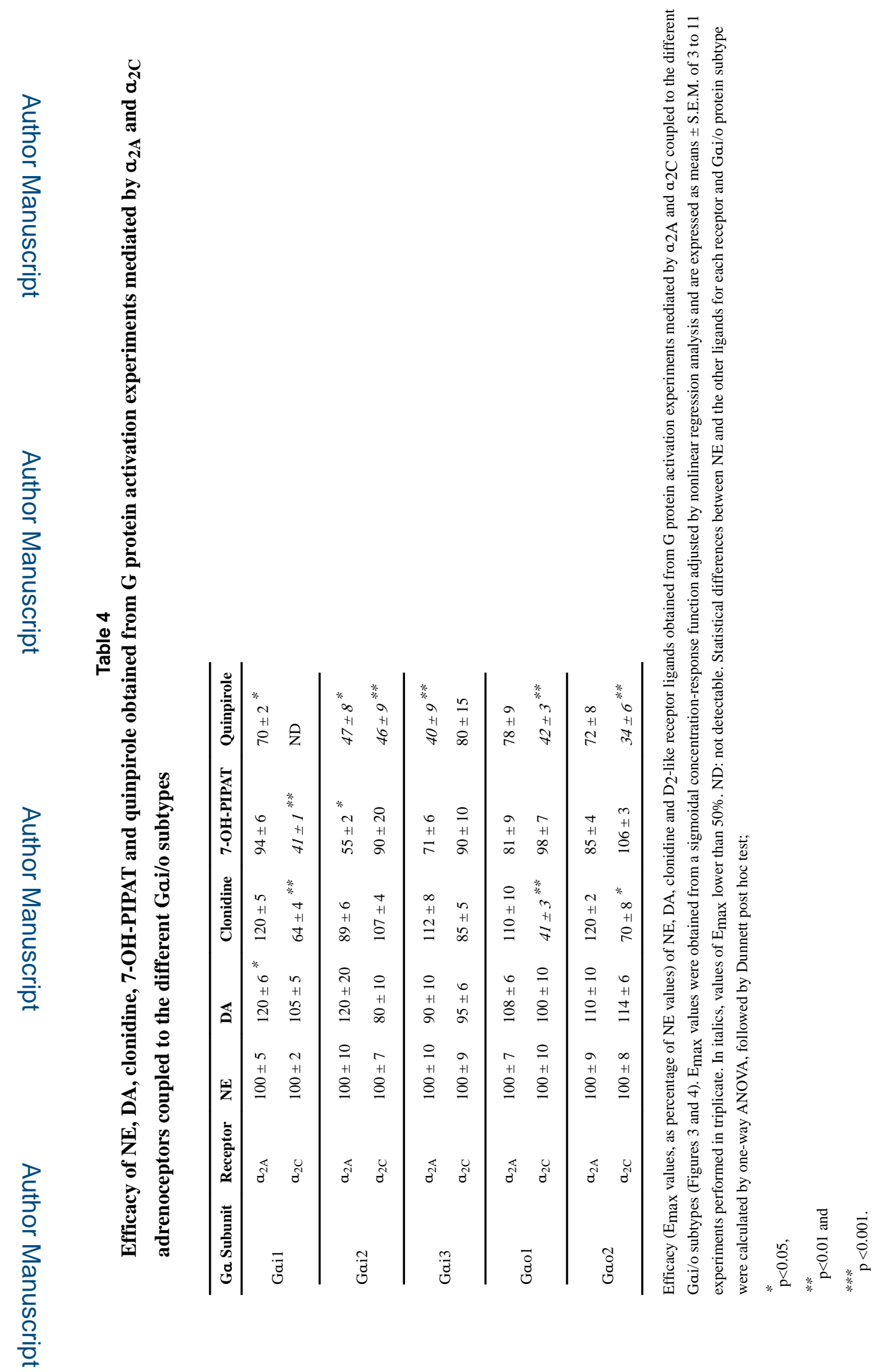

Mol Neurobiol. Author manuscript; available in PMC 2019 November 01. 